\title{
Article \\ Safety and Protective Activities of Manufactured Alcohol-Free Beers
}

\author{
Tania Merinas-Amo ${ }^{1, * \mathbb{D}}$, Mercedes Del Río Celestino ${ }^{2} \mathbb{D}$, Rafael Font ${ }^{2}$ and Ángeles Alonso-Moraga ${ }^{1}$ \\ 1 Department of Genetics, University of Córdoba, 14071 Córdoba, Spain; ge1almoa@uco.es \\ 2 Agri-Food Laboratory, CAGPDS, Avd. Menéndez Pidal, s/n, 14080 Córdoba, Spain; \\ mercedes.rio.celestino@juntadeandalucia.es (M.D.R.C.); rafaelm.font@juntadeandalucia.es (R.F.) \\ * Correspondence: tania.meram@gmail.com; Tel.: +34-957218674; Fax: +34-957212072
}

check for updates

Citation: Merinas-Amo, T.; Del Río Celestino, M.; Font, R.; AlonsoMoraga, Á. Safety and Protective Activities of Manufactured Alcohol-Free Beers. Processes 2022, 10, 331. https://doi.org/10.3390/ pr10020331

Academic Editor: Dariusz Dziki

Received: 26 December 2021

Accepted: 7 February 2022

Published: 9 February 2022

Publisher's Note: MDPI stays neutral with regard to jurisdictional claims in published maps and institutional affiliations.

Copyright: (C) 2022 by the authors. Licensee MDPI, Basel, Switzerland. This article is an open access article distributed under the terms and conditions of the Creative Commons Attribution (CC BY) license (https:// creativecommons.org/licenses/by/ $4.0 /)$.

\begin{abstract}
Nowadays, a general interest in improving health in order to achieve better conditions of life is increasing. Diet is a complex factor affecting health conditions. We analysed the biological activities of three types of alcohol-free lager beer (a blond, a pale-blond and a stout beer) as well as epicatechin gallate (ECG) as one of their most abundant phenols with the aim of revealing them as nutraceuticals. For that purpose, we carried out safety and protective assays of the tested substances in the well-known Drosophila melanogaster animal model. Moreover, chemoprevention studies on human leukaemia cells (HL-60) in an in vitro model were carried out to evaluate the viability and genomic damage potential of the studied compounds on the tumour cell line. Results suggest the safety properties of all compounds, although pale-blond and stout beer only showed genotoxic activity at the lowest concentrations assayed. Moreover, alcohol-free beers and phenols were able to protect against $\mathrm{H}_{2} \mathrm{O}_{2}$ oxidative damage as well as to induce an increase in longevity with an improvement of the quality of life in the in vivo animal model assayed. Promising results were obtained with the alcohol-free beers and ECG in the in vitro assays with human leukaemia cells as they inhibited the tumour cells' growth, induced DNA damage and modified the methylation status of such a cancer cell line. To sum up, alcohol-free beers should be of interest not only because of their reduced calories and isotonic properties but because they can be recognised as nutraceutical substances.
\end{abstract}

Keywords: alcohol-free beer; cytotoxicity; DNA damage; Drosophila melanogaster; epicatechin gallate; genotoxicity; HL-60 cell line; lifespan; methylation status; toxicity

\section{Introduction}

Beer is now being considered as a beverage with potential added value in the diet. Beer consumption has been associated with a wide range of beneficial health effects such as the prevention of cardiovascular disease and a decreased risk of kidney stone formation, chemopreventive activity, antioxidant capacity and physiological effects, among others [1-4]. The sugars, minerals, B vitamins and other available bioactive substances found in beer are conducive to its consideration as a nutritional supplement [5].

Beer is a complex beverage, containing a wide range of constituents. About $20-30 \%$ of beer polyphenols originate from hops, whereas 70-80\% are malt-derived [6]. Additionally, some unique bioactive compounds have been identified in beers as hop-derived prenylflavonoids, including xanthohumol, isoxanthohumol and 8-prenylnaringenin [6], showing promising xanthohumol and iso-alpha humulone properties (safe, protective and cytotoxic with chemoprotective effects) $[7,8]$. Numerous proanthocyanidins, phenolic compounds formed from single monomer units such as the $(-)$-epicatechin, are present in beer. Up to $30 \%$ of the proanthocyanidins present in beer are derived from hops (e.g., epicatechin gallate); the rest are derived from the malt $[9,10]$. ECG $((-)$-epicatechin gallate) is a three-gallate ester form of (-)-epicatechin that, like other phenols, is found in beer in relatively high concentrations (5-20 mg/L) [10]. ECG is present in green tea and also in 
other plants such as grapes, strawberries and buckwheat. This phenol was selected for this study because (apart from the iso-alpha-acids (iso-Cohumulone and iso-n-Humulone) and tyrosol) it is the most abundant phenolic in beer, reaching a concentration of up to $20 \mathrm{mg} / \mathrm{mL}$ [6]. This value is within one order of magnitude of the range of green tea's ECG content ( $8 \mathrm{mg} / \mathrm{g} \mathrm{dw}$ ) [11]. Many studies support the health benefits of ECG mostly due to its antioxidant properties. ECG contributes to reducing the risk of cancer and cardiovascular-related disease and has antiviral and antibacterial activities, ultraviolet protection of skin and neuroprotective power, among properties [12]. Bartolomé et al. [13] and McMurrough and Baert [14] recorded the presence of (-)-epicatechin in alcohol-free beers.

Despite the wide variety of styles of beer, they generally fall into two classes: lager and ale beer. The two categories of beer differ from each other in the type of yeast and temperature used during the brewing process. Lager beers use special yeast that ferments best at cooler temperatures, whereas ale beers use another type of yeast that ferments better at warmer temperatures [15]. Moreover, beers can exhibit colours ranging from pale to black due to the colour of malt(s) caused by the caramelisation of sugars and Maillard-type reactions $[16,17]$. Having beers brewed with dark malts results in a longer shelf life than that of pale beers [18]; furthermore, they differ from pale malts in their colour due to the Maillard reaction or caramelisation of products formed during the roasting of malt by reactions involving proteins and carbohydrates [19]. Although the possible effects that the Maillard reaction and caramelisation process have on the oxidative stability of beer are unknown, positive correlations between antioxidant activity and malt colour have been observed due to the phenols' compositions and the presence of Maillard components $[19,20]$.

Recently, a worldwide interest in alcohol-free (AFB) and low-alcohol beers (LAB) has been increasing. AFB and LAB are known to have a weaker aroma than standard beers [21]. Legally fixed maximum alcohol contents differ among countries, but AFB and LAB are defined as beers with an alcohol content below $0.5 \%$ and no more than $1.2 \%$ alcohol, respectively, for the total volume [21].

Two procedures have been established for manufacturing non-alcoholic beer: (a) physical methods based on removing the alcohol content (dealcoholisation by vacuum rectification and evaporation, dialysis, reverse osmosis, membrane extraction, $\mathrm{CO}_{2}$ extraction, pervaporation, adsorption or freezing), and (b) biological processes based on limited alcohol formation by using a special yeast [21-25]. The most commonly used yeast for alcohol-free beer production is Saccharomycodes ludwigii. It has the capacity to control the fermentation process due to its inability to ferment the prevailing fermentable sugars in all malt worts (maltose and maltotriose). Moreover, the fermentation of S. ludwigii does not require continuous monitoring as it is a slow attenuation process at $20^{\circ} \mathrm{C}$ [21].

There is a scarcity of literature on comparisons of the two processes and their effects on product quality and the cost of brewing LABs or AFBs. Nonetheless, the arrested/limited fermentation process may be easily carried out with standard brewery equipment, resulting in a quicker production time and requiring fewer raw materials. As a result, the manufacturing charges of LAB/AFBs are comparable to or even less than those generated from producing normal beer. Alcohol removal processes, on the other hand, necessitate additional equipment, utilities and space, implying additional investments and operating costs above the price of producing conventional dealcoholised beer. The alcohol separation procedures are, however, flexible (the more hours, the higher output) and can generate zero-alcohol beers, which is difficult to achieve using natural fermentative processes [21].

Phenol content (type and concentration) in beer is related to the raw materials utilised, the brewing process and also the change during storage after manufacturing. Alcohol-free beer usually has lower levels of phenolic content due to the differences in the duration of fermentation and the yeast strains employed in their brewing and to losses during the dealcoholisation process [10,13].

The final outcome of a specific beer is the result of multifactorial entries (composition, alcohol content, brewing process), and hence, the exhaustive study of beer becomes complicated. Nevertheless, it is known that recently there has been an increasing interest 
in health care and, consequently, a new lifestyle emerging. For these reasons, we studied one of the most consumed beverages as it is believed to be healthier: alcohol-free beers. A new data corpus is needed not only for their brewing process, phenol content or flavour but also to assess their safety, genome-protecting and longevity-enhancing activities. The aim of the present research was to evaluate the safety, protective and chemopreventive activities of three types of alcohol-free lager beers (a blond, a pale-blond and a stout beer variety) and the common and most abundant phenol in all of them (ECG). For that purpose, the Drosophila animal model used for safety and protective assays, which contains more than $70 \%$ of genes homologous with human disease [26,27], is a reliable system for in vivo screening assessing tests. Moreover, chemopreventive studies in the in vitro model of the human leukaemia cell line (HL-60) were carried out to evaluate the cytotoxic and DNA clastogenic potency that our tested compounds induced in the tumour cells.

\section{Materials and Methods}

\subsection{Samples Preparation and Single Compounds}

A blond alcohol-free lager beer (Bucker $0,0{ }^{\circledR}$ ) (LBAFLB), a pale-blond alcohol-free lager beer (Pale Buckler 0,0 ${ }^{\circledR}$ ) (LPBAFLB) and a stout alcohol-free lager beer (Stout Buckler $\left.0,{ }^{\circledR}\right)$ (LSAFLB) were selected for this study. All beers are characterised by an alcohol volume $\leq 0.04 \%$ and the use of special yeast (S. ludwigii) during their brewing. It should be noticed that LPBAFLB is characterised by the addition of food additives such as the E-414 stabiliser and the E-330 acidulant. Furthermore, taking into account that alcohol-free beers have the same bioactive compounds (although in lower concentrations) than regular beer except for alcohol [28], epicatechin gallate (ECG) was tested as a single bioactive compound as it is the third most abundant phenol in beers after tyrosol and iso-alpha humulone [6] and has not been studied in our previous research [8].

Only alcohol-free lager beers were chosen for the present study as they claim the highest consumption rate in the world with respect to alcohol-free ale. This could be related with the economic impact that ale beers may have in the dealcoholisation process as well as the brewing process (top-fermenting yeast at warm temperatures), and they have a much higher alcohol content than lagers [29].

Beers samples were lyophilised before the assays were carried out (SCAI, University of Córdoba) and stored until use at room temperature in a dark and dry atmosphere. Lyophilised beers were dissolved in distilled water to obtain the different concentrations to be tested.

The concentrations of beers tested were established for the purpose of comparing them to the daily beer intake of humans $(192 \mathrm{~mL}$ of total beer/day for $70 \mathrm{~kg}$ of human body weight) [30] with the average daily food intake of Drosophila (1 mg/day) and the average body weight of $D$. melanogaster individuals (1 mg) [31]. Furthermore, the assayed concentrations of ECG were the equivalent to those contained in the full beer.

\subsection{Model System Used}

\subsubsection{In Vivo: D. melanogaster}

The exceptional characteristics that Drosophila possesses, such as a short life cycle and reliability, make this eukaria an ideal model organism. Furthermore, Drosophila shows a consistent genetic similarity to humans, taking into account that just about $75 \%$ of the genes involved in human diseases have related or similar sequences to those in $D$. melanogaster [32,33], which makes this organism the choice model for toxicology, developmental biology, genetics and evolutionary studies [34-38].

Two Drosophila strains were used, each one characterised by a distinctive hair marker in the third chromosome:

- $\quad m w h / m w h$ : holds the recessive mutation mwh (multiple wing hairs) that produces multiple tricomas per cell instead of one when homozygous [39]. 
- $\quad f l r^{3} / I n$ (3LR) TM3, rippsep $b x^{34 e} e^{s} B d^{S}$ : the $f l r^{3}$ (flare) marker is a homozygous recessive lethal mutation that causes deformed tricomas to appear, but once larvae begin development it is viable in homozygous somatic cells [40].

\subsubsection{In Vitro: HL-60 Promyelocytic Human Leukaemia Cells}

The HL-60 cell line originated from a female patient with acute myeloid leukaemia [41]. The growing of peripheral blood leukocytes from this subject in conditioned medium proceeded the expansion of a growth-factor-independent immortal cell line with distinct myeloid characteristics [42]. The promyelocytic human leukaemia cell line HL-60 proliferates in suspension culture with a doubling time of about 36 to $48 \mathrm{~h}$.

Cells were cultured in supplemented RPMI-1640 medium (Sigma-Aldrich, St. Louis, $\mathrm{MO}$, USA, R5886) at $37{ }^{\circ} \mathrm{C}$ and $5 \% \mathrm{CO}_{2}$ conditions [42]. The cultures were plated at $2.5 \times 10^{4}$ cells $/ \mathrm{mL}$ density in $10 \mathrm{~mL}$ culture bottles and replaced three times per week.

\subsection{Safety In Vivo Assays}

\subsubsection{Toxicity}

The percentage of the number of individuals hatched in each treatment compared to the number of individuals hatched in the negative control was analysed at the following ranks of concentrations for the different beers, which fell between 3.125 and $50 \mathrm{mg} / \mathrm{mL}$. For ECG the concentrations used were those equivalent to its quantity in the total volume of beer $(0.0048-0.079 \mathrm{mM})$. Treatment tubes contained $0.85 \mathrm{~g}$ of Drosophila Instant Medium (Formula 4-24, Carolina Biological Supply Company, Burlington, NC, USA) and $4 \mathrm{~mL}$ of each different concentration of the substance to be tested. The negative controls were composed of medium and distilled water.

Chi-square test in Microsoft Office Excel 2007 was used to estimate if the tested compounds affected the survival of flies in a significant way.

\subsubsection{Genotoxicity}

The genotoxicity assays were performed using the method described by Graf et al. [27]. Assayed concentrations ( 3.125 and $50 \mathrm{mg} / \mathrm{mL}$ beer and 0.0048 and $0.079 \mathrm{mM} \mathrm{ECG)} \mathrm{were}$ prepared in the same way as described in the toxicity section. After emergence, adult flies were stored in $70 \%$ ethanol until the wings were mounted and scrutinised for mutations at $400 \times$ magnification. Transheterozygous wings $\left(m w h \mathrm{flr}^{+} / \mathrm{mwh}^{+} \mathrm{flr}{ }^{3}\right)$ show spots corresponding to different events (somatic point mutation, deletions, non-disjunction and somatic recombination of both $m w h$ and $f l r$ genetic markers).

A total of 207 wings were mounted, and the total number of spots were analysed by a multiple-decision procedure to determine whether a result was positive, inconclusive or negative [43]. The frequencies of each obtained type of mutant clone were analysed applying the binomial Kastenbaum and Bowman Test [44], without Bonferroni correction and at $5 \%$ level of significance, and compared with the concurrent control. All inconclusive and positive results were analysed with the nonparametric Mann-Whitney U-test $(\alpha=\beta=0.05)$.

A total of 40 wings for each positive concentration $(3.125 \mathrm{gm} / \mathrm{mL})$ of LPBAFLB and LSAFLB with balancer marker $\left(m w h / B d^{S}\right)$ at their single treatments were also tested in order to evaluate the percentage of genotoxic activity present due to somatic recombinogenic events $(R)$ of the substance using the following formula [45]:

$$
\mathrm{R}=[1-(m w h \text { spots on the balancer wings } / m w h \text { spots on the marker wings })] \times 100
$$

\subsection{Protection In Vivo Tests}

\subsubsection{Antitoxicity}

The antitoxicity tests in the study revealed the viability percentage of Drosophila treated with the same concentrations as in toxicity assays combined with the genotoxicant $\mathrm{H}_{2} \mathrm{O}_{2}$ 
at $0.12 \mathrm{M}$ [46]. The positive controls were prepared with medium and $0.12 \mathrm{M} \mathrm{H}_{2} \mathrm{O}_{2}$ as an oxidative genotoxicant.

Chi-square test in Microsoft Office Excel 2007 was used to determine if the tested compounds significantly affected the survival of flies.

\subsubsection{Antigenotoxicity}

The antigenotoxicity trials were performed according to Graf et al. [47], which included combined treatments of genotoxin $\left(0.12 \mathrm{M} \mathrm{H}_{2} \mathrm{O}_{2}\right)$ and the same concentration used in genotoxicity assays ( 3.125 and $50 \mathrm{mg} / \mathrm{mL}$ beer; 0.0048 and $0.079 \mathrm{mM} \mathrm{ECG).} \mathrm{After} \mathrm{emergence,}$ the same steps as those taken for the genotoxicity assays were carried out to mount and scrutinise the wings. A total of 196 wings were mounted and analysed. The inhibition percentages (IP) for the combined treatments were calculated from total spots per wing with the following formula [48]:

$$
\mathrm{IP}=[(\text { single genotoxin }- \text { combined treatment }) / \text { single genotoxin }] \times 100
$$

\subsubsection{Longevity}

All lifespan trials were performed at $25^{\circ} \mathrm{C}$ according to the procedure described in Tasset-Cuevas et al. [46]. Four replicas were studied during the complete life extension for each control and concentration established $(3.125-50 \mathrm{mg} / \mathrm{mL}$ beer and $0.0048-0.079 \mathrm{mM}$ ECG). Alive animals were counted, and the respective media were renewed twice a week. Healthspan data were also obtained by studying the upper $25 \%$ of the curve, characterised by low and nearly constant age-specific mortality rate values [49].

The statistical treatment of survival data for each control and concentration were assessed with the SPSS Statistics 17.0 software (SPSS, Inc., Chicago, IL, USA), applying the Kaplan-Meier method. The significance of the curves was determined using the log-rank method (Mantel-Cox).

\subsection{Protection In Vitro Tests}

\subsubsection{Cytotoxicity Assay}

HL-60 cells were placed in 96-well culture plates $\left(2 \times 10^{4}\right.$ cells $\left./ \mathrm{mL}\right)$ and treated for $72 \mathrm{~h}$ with the different beers $(7.81-250 \mathrm{mg} / \mathrm{mL}$ for LBAFLB; $0.488-250 \mathrm{mg} / \mathrm{mL}$ for LPBAFLB and LSAFLB) and the equivalent concentrations for ECG $(0.0048-0.079 \mathrm{mM})$. This wide range was selected to rate a variety of cytotoxic doses including the inhibitory concentration $50\left(\mathrm{IC}_{50}\right)$ when possible. This allowed the evaluation of a wide range of concentrations in the cell viability assays, which let us to predict acute in vitro lethality.

Cell viability was determined by the trypan blue dye (Sigma-Aldrich, St. Louis, MO, USA, T8154) exclusion test in a Neubauer chamber at 100 $\times$ magnification (AE30/31, Motic). Cytotoxicity curves at $72 \mathrm{~h}$ were determined as the average survival percentage of three independent experiments compared to that of the control.

\subsubsection{Tumour Cells' DNA Damage Evaluation \\ DNA Fragmentation}

HL-60 cells $\left(1 \times 10^{6}\right.$ cells $\left./ \mathrm{mL}\right)$ were treated with different concentrations of selected blond and stout lyophilised beers $(15.625-250 \mathrm{mg} / \mathrm{mL})$ and their equivalent concentration of ECG $(0.0048-0.79 \mathrm{mM})$ for $5 \mathrm{~h}$.

Treated cells were collected following the protocol carried out in our laboratory [7] with lysis, precipitation and washing steps. Finally, DNA was quantified, subjected to a $2 \%$ agarose gel electrophoresis and visualised under UV light. A DNA-size ladder (GTP Bio) was run in parallel with DNA molecular weight reference. 


\section{Comet Assay}

Cells were treated with different concentrations of lyophilised beers $(15.625,31.25$ and $62.5 \mathrm{mg} / \mathrm{mL})$ and their equivalent concentrations of ECG $(0.0048,0.0097$ and $0.0195 \mathrm{mM})$ for $5 \mathrm{~h}$.

Cells were mixed with $0.75 \%$ low-melting-point agarose (Sigma-Aldrich, St. Louis, MO, USA, A4018) and transferred to frosted-end slides followed by steps of lysis, alkaline electrophoresis and neutralization and dried according to Mateo-Fernández et al.'s [50] protocol. Finally, DNA of 50-100 single cells was visualised using a Leica DM 2500 fluorescence microscope with green filter and an attached camera (JAI CV-M4CL).

Statistical analysis of data was performed using SPSS Statistic 17.0 software. The tail moment data were evaluated by a one-way ANOVA. The post hoc Tukey's test was applied to assess the effect of the compounds on HL-60 cells' DNA integrity. Statistical significance was considered $p \leq 0.05$.

\section{Methylation Status}

Genomic DNA from beer (15.625 and $250 \mathrm{mg} / \mathrm{mL})$ and ECG (0.0048 and $0.079 \mathrm{mM})$ treatments was isolated following the protocol used in the DNA fragmentation assays. Bisulphite-modified DNA, using the EZ DNA Methylation-Gold Kit, was used as a template for fluorescence-based real-time quantitative methylation-specific PCR (qMSP) according to the protocol described by Merinas-Amo et al. [7]. qMSP was performed in 48-well plates in MiniOpticon Real-Time PCR System (MJ Mini Personal Thermal Cycler, Bio-Rad) and analysed by Bio-Rad CFX Manager 3.1 (Bio-Rad, Hercules, California).

Three different repetitive elements (Alu M1, LINE-1 and Sat- $\alpha$ ) (Isogen Life Science) were chosen with the aim of studying extensive human genomic DNA. The Alu and LINE sequences are distributed throughout the genome in a random way; meanwhile, satellites are restricted to the centromere areas [51-54]. Complete information about Alu M1, LINE-1 and Sat- $\alpha$ sequences is described in Table 1 [55].

Table 1. Primer information.

\begin{tabular}{|c|c|c|c|c|c|c|c|}
\hline \multirow{2}{*}{ Reaction ID } & \multirow{2}{*}{$\begin{array}{l}\text { GenBank } \\
\text { Number }\end{array}$} & \multirow{2}{*}{$\begin{array}{l}\text { Amplicon } \\
\text { Start }\end{array}$} & \multirow{2}{*}{$\begin{array}{l}\text { Amplicon } \\
\text { End }\end{array}$} & \multirow{2}{*}{$\begin{array}{c}\text { Forward Primer } \\
\text { Sequence } 5^{\prime} \text { to } 3^{\prime}(\mathrm{N})\end{array}$} & \multirow{2}{*}{$\begin{array}{c}\text { Reverse Primer } \\
\text { Sequence } 5^{\prime} \text { to } 3^{\prime}(\mathrm{N})\end{array}$} & \multicolumn{2}{|c|}{ GC-Content (\%) } \\
\hline & & & & & & Forward & Reverse \\
\hline ALU-C4 & $\begin{array}{l}\text { Consensus } \\
\text { Sequence }\end{array}$ & 1 & 98 & $\begin{array}{l}\text { GGTTAGGTATAGTGGTTTATATTTGTAA- } \\
\text { TTTTAGTA } \\
(36)\end{array}$ & $\begin{array}{c}\text { ATTAACTAAACTAATCTTAAACTCCT- } \\
\text { AACCTCA } \\
(33)\end{array}$ & 25 & 27.3 \\
\hline ALU M1 & Y07755 & 5059 & 5164 & $\begin{array}{l}\text { ATTATGTTAGTTAGGATGGTTTCGATTTT } \\
\qquad(29)\end{array}$ & CAATCGACCGAACGCGA (17) & 27.6 & 58.8 \\
\hline LINE-1 & X52235 & 251 & 331 & GGACGTATTTGGAAAATCGGG (21) & AATCTCGCGATACGCCGTT (19) & 47.6 & 52.6 \\
\hline Sat- $\alpha$ & M38468 & 139 & 260 & $\begin{array}{l}\text { TGATGGAGTATTTTTAAAATATACGTTTT- } \\
\text { GTAGT } \\
(34)\end{array}$ & $\begin{array}{l}\text { AATTCTAAAAATATTCCTCTTCAATTA- } \\
\text { CGTAAA } \\
(33)\end{array}$ & 23.5 & 21.2 \\
\hline
\end{tabular}

Source Weisenberger et al. [55].

The relative yielded results were normalised by using the Alu C4 sequence as housekeeping according to Nikolaidis et al. [56] and Liloglou et al.'s [57] comparative Ct method. After triplicate assays were performed for each sample, results were analysed with one-way ANOVA and post hoc Tukey's statistical tests.

\section{Results and Discussion}

\subsection{Safety: Toxicity and Genotoxicity}

The toxicity of LBAFLB, LPBAFLB, LSAFLB and ECG was evaluated in the Drosophila in vivo model. After treating larvae with different concentrations of the studied substances, results show a non-significant survival rate compared to that of the control at all of the concentrations tested, exhibiting a non-toxic effect on Drosophila's viability (Figure 1). 
LBAFLB

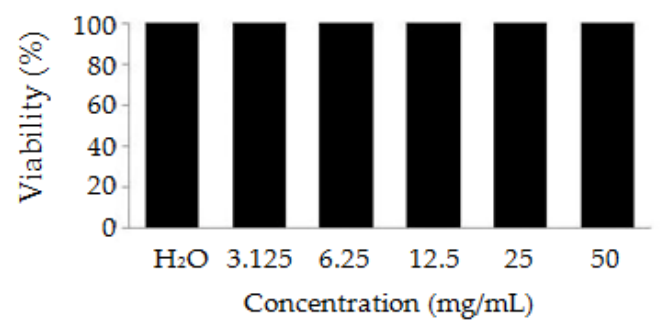

LSAFLB

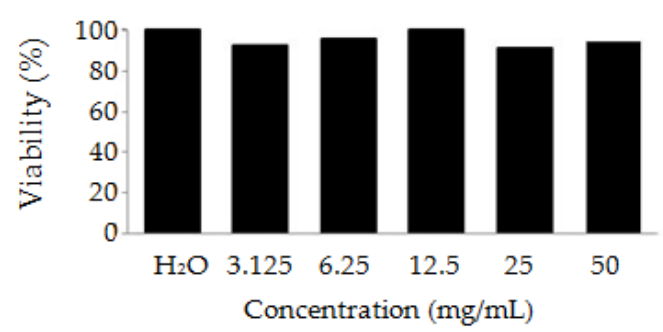

LPBAFLB

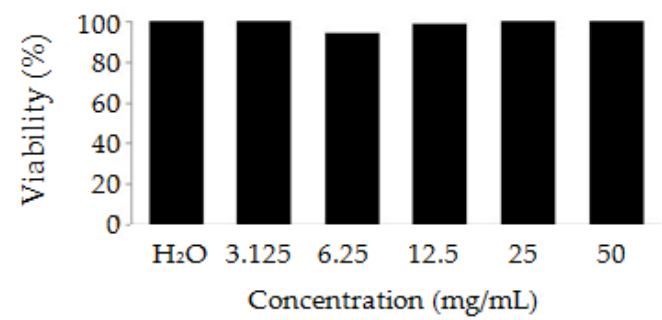

ECG

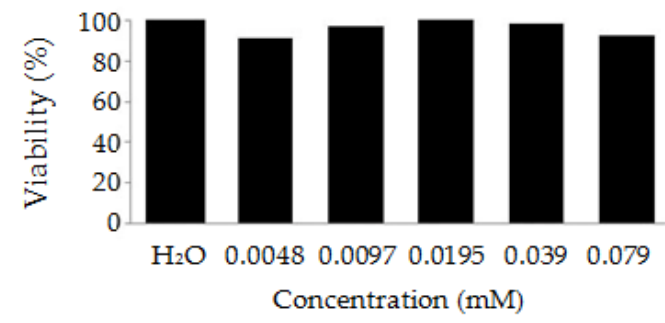

Figure 1. Toxicity levels of lyophilised blond alcohol-free beer (LBAFLB), lyophilised pale-blond alcohol-free beer (LPBAFLB), lyophilised stout alcohol-free lager beer (LSAFLB) and epicatechin gallate (ECG) in D. melanogaster. Data are expressed as percentage of surviving adults with respect to 300 untreated 72-hour-old larvae from three independent experiments treated with different concentrations of LBAFLB, LPBAFLB, LSAFLB and ECG.

Results of genotoxicity assays in the SMART test are indicated in Table 2. The frequency of mutations per wing in the negative control test (0.157) falls into the biographical range for the wing spot test [58]. The results show that all the compounds assayed appear to have no genotoxic effect at the tested concentrations, except for the lowest concentrations $(3.125 \mathrm{mg} / \mathrm{mL})$ of the LPBAFLB and LSAFLB, which showed a significantly higher total mutation rate ( 0.575 and 0.452 spots/wings, respectively) than that of the negative control (0.157 spots/wing). In the balancer-heterozygous genotype (mwh/TM3) mwh spots were produced mainly by somatic point mutation and chromosome aberrations. By scoring $m w h / T M 3$ balancers-heterozygous wings, the quantification of the recombinogenic potency of the positive control was possible. The frequency of mwh clones on the marker transheterozygous wings ( $m w$ h single spots plus twin spots) was compared with the frequency of mwh spots on the balancer transheterozygous wings. The difference in mwh clone frequency is a direct measure of the proportion of recombination. Recombinogenicity values for genotoxic beers were $78.39 \%$ for LPBAFLB and $83.24 \%$ for LSAFLB, which were slightly higher than that of their respective control treatment (74.5\%). Consequently, our compounds induced mutagenic activity instead of recombinogenic activity.

Although beer is known to have healthy properties including anti-bacterial, antiinflammatory and anti-oxidative effect, it is associated with a lower risk of cardiovascular disease, and few studies have been performed with this beverage in the Drosophila animal model. A previous similar study by Merinas-Amo et al. [7] with an alcoholic lyophilised blond lager beer showed that it does not exhibit toxicity at the assayed concentrations with $100 \%$ survival compared to the control; moreover, they revealed that beer showed nongenotoxic effects in the Drosophila SMART test with significant similar or lower values of mutation rates at the different concentrations tested compared with the negative control [7]. 
Table 2. Genotoxicity of lyophilised blond alcohol-free lager beer (LBAFLB), lyophilised pale-blond alcohol-free lager beer (LPBAFLB), lyophilised stout alcohol-free lager beer (LSAFLB) and epicatechin gallate (ECG) in the Drosophila wing spot test.

\begin{tabular}{|c|c|c|c|c|c|c|c|c|}
\hline \multirow[b]{2}{*}{ Compound } & \multicolumn{5}{|c|}{ Clones Per Wing (No. of Spots) ${ }^{(1)}$} & \multirow[b]{2}{*}{$F^{(2)}$} & \multirow[b]{2}{*}{ U-Test ${ }^{(3)}$} & \multirow[b]{2}{*}{$\mathbf{R}(\%){ }^{(4)}$} \\
\hline & $\begin{array}{l}\text { No of } \\
\text { Wings }\end{array}$ & $\begin{array}{l}\text { Small Single } \\
\text { Clones (1-2 } \\
\text { Cells) } \mathrm{m}=2\end{array}$ & $\begin{array}{c}\text { Large Single } \\
\text { Clones }(>2 \\
\text { Cells) } \mathrm{m}=5\end{array}$ & $\begin{array}{c}\text { Twin Clones } \\
\mathrm{m}=5\end{array}$ & $\begin{array}{c}\text { Total Clones } \\
\quad \mathbf{m}=2\end{array}$ & & & \\
\hline \multicolumn{9}{|c|}{ Single Treatment $\left(m w h / f l r^{3}\right)$} \\
\hline $\mathrm{H}_{2} \mathrm{O}$ & 38 & $0.157(6)$ & 0 & 0 & $0.157(6)$ & 0.650 & & 76.92 \\
\hline \multicolumn{9}{|c|}{ LBAFLB (mg/mL) } \\
\hline 3.125 & 47 & $0.255(12)$ & $0.0212(1)$ & 0 & $0.276(13) \mathrm{i}$ & 1.134 & $\Delta$ & \\
\hline 50 & 45 & $0.288(13)$ & 0 & 0 & $0.288(13) \mathrm{i}$ & 1.184 & $\Delta$ & \\
\hline \multicolumn{9}{|c|}{ LPBAFLB $(\mathrm{mg} / \mathrm{mL})$} \\
\hline 3.125 & 40 & $0.450(18)$ & $0.15(5)$ & 0 & $0.575(23)+$ & 2.360 & & 78.39 \\
\hline 50 & 40 & $0.225(9)$ & $0.075(3)$ & 0 & $0.300(12) \mathrm{i}$ & 1.230 & $\Delta$ & \\
\hline \multicolumn{9}{|c|}{ LSAFLB (mg/mL) } \\
\hline 3.125 & 42 & $0.357(15)$ & $0.095(4)$ & 0 & $0.452(19)+$ & 1.850 & & 83.24 \\
\hline 50 & 32 & $0.281(9)$ & $0.094(3)$ & 0 & $0.375(12) \mathrm{i}$ & 1.665 & $\Delta$ & \\
\hline \multicolumn{9}{|c|}{ ECG $(\mathrm{mM})$} \\
\hline 0.0048 & 38 & $0.210(8)$ & $0.052(2)$ & 0 & $0.263(10) \mathrm{i}$ & 1.079 & $\Delta$ & \\
\hline 0.079 & 40 & $0.175(7)$ & $0.025(1)$ & 0 & $0.200(8) \mathrm{i}$ & 0.820 & $\Delta$ & \\
\hline \multicolumn{9}{|c|}{ Single Treatment (mwh/TM3) } \\
\hline $\mathrm{H}_{2} \mathrm{O}^{(5)}$ & 80 & $0.040(3)$ & 0 & 0 & $0.040(3)$ & 0.150 & & \\
\hline \multicolumn{9}{|c|}{ LPBAFLB (mg/mL) } \\
\hline 3.125 & 40 & $0.125(5)$ & 0 & 0 & $0.125(5)$ & 0.510 & & \\
\hline \multicolumn{9}{|c|}{ LSAFLB (mg/mL) } \\
\hline 3.125 & 40 & $0.075(3)$ & 0 & 0 & $0.075(3)$ & 0.310 & & \\
\hline
\end{tabular}

(1) Statistical diagnosis according to Frei and Wurgler [43]. + (positive), - (negative) and i (inconclusive) versus negative control. m: multiplication factor. Kastenbaum-Bowman Test without Bonferroni correction, probability levels $\alpha=\beta=0.05$. (2) Frequency of clone formation per $10^{5}$ cells: clones/wings/24,400 cells. ${ }^{(3)}$ Inconclusive results were resolved by Mann-Whitney U-test. Delta marker $(\Delta)$ means no differences between the treatment and the concurrent control. ${ }^{(4)}$ Recombination percentage was calculated according to Valadares, Graf and Spanó [45]. ${ }^{(5)}$ Balancers-heterozygous wings.

\subsection{Protection: Antitoxicity, Antigenotoxicity and Longevity}

The antitoxicity assays revealed the ability of LBAFLB, LPBAFLB, LSAFLB and ECG to protect the individuals against oxidative stress at some of the tested concentrations. Figure 2 shows that the positive control $\mathrm{H}_{2} \mathrm{O}_{2}$ is toxic at $0.12 \mathrm{M}$ with an average survival rate of $54 \%$ with respect to the water control. LBAFLB showed a significant protection against the genotoxicant at the two highest concentrations tested (25 and $50 \mathrm{mg} / \mathrm{mL}$ ). LPBAFLB also showed a significant protective effect at 6.25 and $12.5 \mathrm{mg} / \mathrm{mL}$ concentrations. LSAFLB only showed a protective effect at the lowest concentration $(3.125 \mathrm{mg} / \mathrm{mL})$. The combined treatment of ECG and $\mathrm{H}_{2} \mathrm{O}_{2}$ showed a significant protective effect at the two lowest concentrations ( 0.0048 and $0.079 \mathrm{mM})$.

Results of antigenotoxicity assays in the SMART test are indicated in Table 3. The concentration of $\mathrm{H}_{2} \mathrm{O}_{2}$ used $(0.12 \mathrm{M})$ has been evidenced to exert a potent genotoxic effect able to induce somatic mutations and mitotic recombination in D. melanogaster [59] at a rate of 0.388 spots/wing. 
LBAFLB

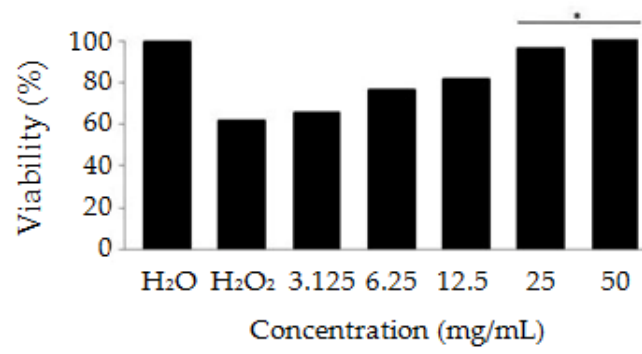

LSAFLB

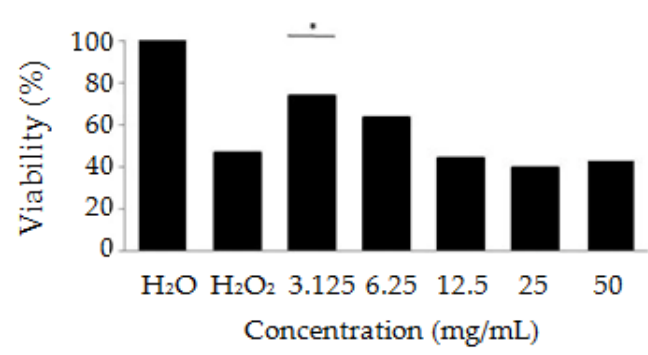

LPBAFLB
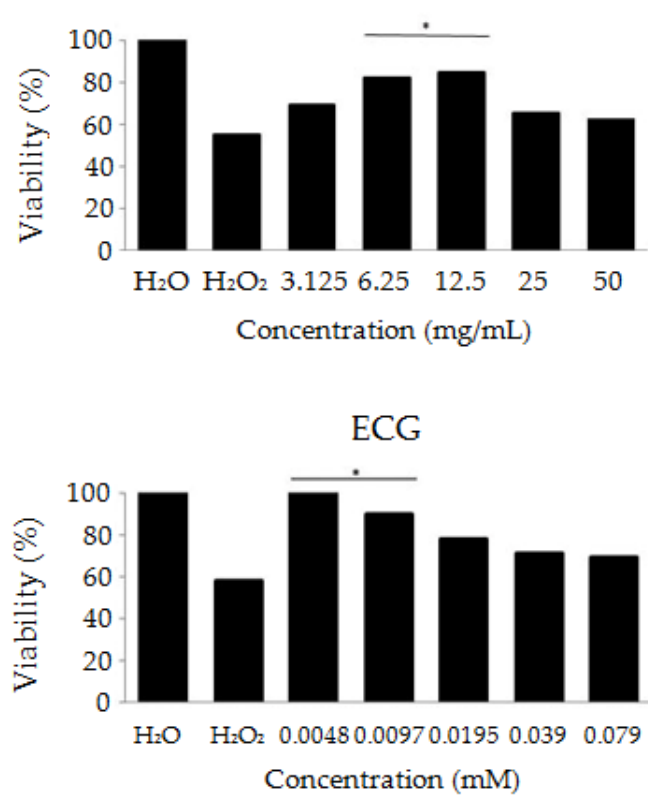

Figure 2. Antitoxicity levels of lyophilised blond alcohol-free lager beer (LBAFLB), lyophilised pale-blond alcohol-free lager beer (LPBAFLB), lyophilised stout alcohol-free lager beer (LSAFLB) and epicatechin gallate (ECG) in D. melanogaster. Data are expressed as percentage of surviving adults with respect to 300 untreated 72-h-old larvae from three independent experiments treated with different concentrations of LBAFLB, LPBAFLB, LSAFLB and ECG combined with $0.12 \mathrm{M} \mathrm{H}_{2} \mathrm{O}_{2}$. *: Chi-square $>3.84(p<0.05)$.

Table 3. Antigenotoxicity of lyophilised blond alcohol-free lager beer (LBAFLB), lyophilised paleblond alcohol-free lager beer (LPBAFLB), lyophilised stout alcohol-free lager beer (LSAFLB) and epicatechin gallate (ECG) in the Drosophila wing spot test.

\begin{tabular}{|c|c|c|c|c|c|c|c|}
\hline \multirow[b]{2}{*}{ Compound } & \multicolumn{5}{|c|}{ Clones Per Wing (No. of Spots) } & \multirow[b]{2}{*}{$F^{(2)}$} & \multirow[b]{2}{*}{ IP (\%) } \\
\hline & $\begin{array}{l}\text { No. of } \\
\text { Wings }\end{array}$ & $\begin{array}{c}\text { Small Single } \\
\text { Clones (1-2 Cells) } \\
\text { m }=2\end{array}$ & $\begin{array}{c}\text { Large Single } \\
\text { Clones (>2 Cells) } \\
m=5\end{array}$ & $\begin{array}{c}\text { Twin Clones } \\
\text { m }=5\end{array}$ & $\begin{array}{c}\text { Total Clones } \\
\text { m }=2\end{array}$ & & \\
\hline $\mathrm{H}_{2} \mathrm{O}$ & 38 & $0.157(6)$ & 0 & 0 & $0.157(6)$ & 0.650 & \\
\hline $\mathrm{H}_{2} \mathrm{O}_{2}$ & 36 & $0.305(11)$ & $0.083(3)$ & 0 & $0.388(14)+$ & 2.049 & \\
\hline \multicolumn{8}{|c|}{ LBAFLB (mg/mL) } \\
\hline 3.125 & 39 & $0.231(9)$ & $0.0512(2)$ & 0 & $0.282(11) \beta$ & 1.156 & 27.32 \\
\hline 50 & 45 & $0.155(7)$ & $0.066(3)$ & 0 & $0.222(10) \beta$ & 0.911 & 42.78 \\
\hline \multicolumn{8}{|c|}{ LPBAFLB $(\mathrm{mg} / \mathrm{mL})$} \\
\hline 3.125 & 44 & $0.295(13)$ & $0.068(3)$ & 0 & 0.363 (16) $\beta$ & 1.490 & 6.44 \\
\hline 50 & 40 & $0.025(10)$ & $0.025(1)$ & 0 & 0.275 (11) $\beta$ & 1.127 & 29.12 \\
\hline \multicolumn{8}{|c|}{ LSAFLB (mg/mL) } \\
\hline 3.125 & 34 & $0.235(8)$ & $0.059(2)$ & 0 & $0.290(10) \beta$ & 1.205 & 25.25 \\
\hline 50 & 40 & $0.150(6)$ & $0.100(4)$ & 0 & $0.250(10) \beta$ & 1.025 & 35.56 \\
\hline \multicolumn{8}{|c|}{ ECG $(\mathrm{mM})$} \\
\hline 0.0048 & 40 & $0.275(11)$ & $0.050(2)$ & 0 & 0.325 (13) $\beta$ & 1.332 & 16.24 \\
\hline 0.079 & 40 & $0.250(10)$ & $0.050(2)$ & $0.050(2)$ & 0.350 (14) $\beta$ & 1.434 & 9.79 \\
\hline
\end{tabular}

(1) Statistical diagnosis according to Frei and Wurgler [43]. $\beta$ (significantly different) versus positive control. $\mathrm{m}$ : multiplication factor. Kastenbaum-Bowman Test without Bonferroni correction, probability levels $\alpha=\beta=0.05$. ${ }^{(2)}$ Frequency of clone formation per $10^{5}$ cells: clones/wings/24,400 cells. ${ }^{(3)}$ The inhibition percentage for the combined treatments was calculated from total spots per wing according to Abraham [48]. 
Results show that LBAFLB, LPBAFLB, LSAFLB and ECG were able to inhibit the genotoxic activity of $\mathrm{H}_{2} \mathrm{O}_{2}$ with inhibition percentages of $27.32-42.78 ; 6.44-29.12 ; 25.25-35.56$; and 16.24-9.79 at the lowest and highest tested concentrations, respectively. There was an apparent contradictory result regarding the significant genotoxicity of the lower concentration of LPBAFLB and LSAFLB. Nevertheless, we hypothesised that a competitive oxidation mechanism may take place between hydrogen peroxide and the mutagenic compounds contained in the studied LPBAFLB and LSAFLB [60].

Results obtained in the different longevity assays are shown in Figure 3 and Table 4. Survival curves show either a similar or a significant increase in lifespan expansion for all compounds compared to their corresponding control, except for the two lowest concentrations of ECG $(0.0048$ and $0.0097 \mathrm{mM})$, which significantly reduced the lifespan of D. melanogaster. LBAFLB and LSAFLB showed a significant increase in life extension in D. melanogaster at all the tested concentrations with an average range of 52.90-66.38 days and 74.179-80.852 days, respectively, compared to the control (47.242 and 69.324 days on average, respectively). LPBAFLB showed a significant increase in life extension in $D$. melanogaster fed with concentrations of 3.125 and $6.25 \mathrm{mg} / \mathrm{mL}$, with a life extension of 6 and 11 days, respectively, compared to the corresponding control. Finally, ECG was able to improve longevity at the two highest concentrations ( 0.039 and $0.079 \mathrm{mM})$; however, the phenol induced a reduction of 10-4 days in the lifespan of Drosophila treated with the respective 0.0048 and $0.0097 \mathrm{mM}$ concentrations, when compared with the control treatment.

A)

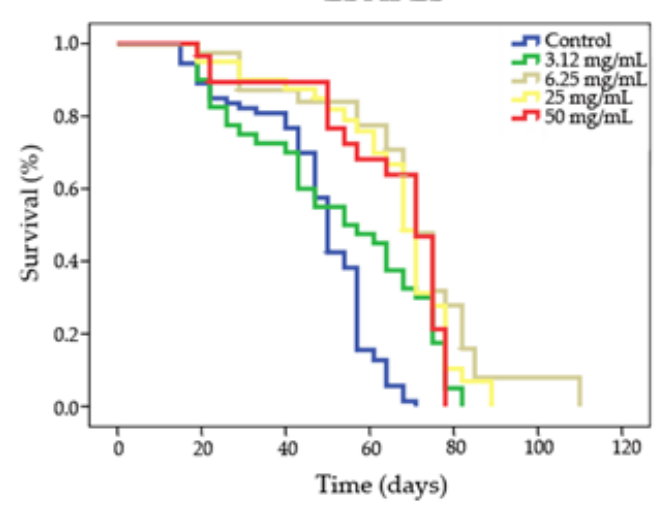

LPBAFLB

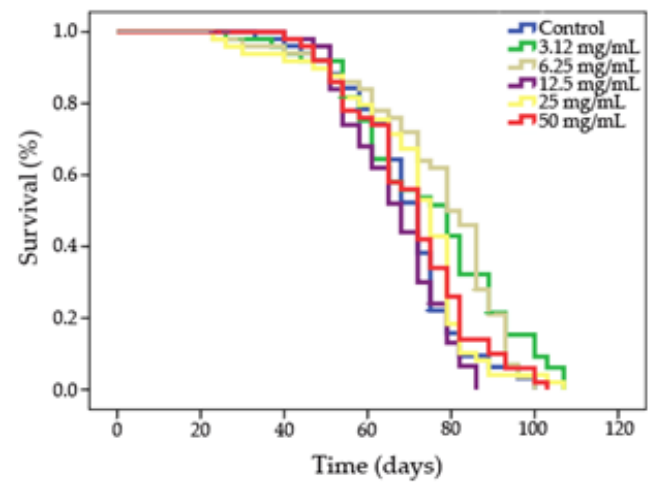

Figure 3. Cont.
B)
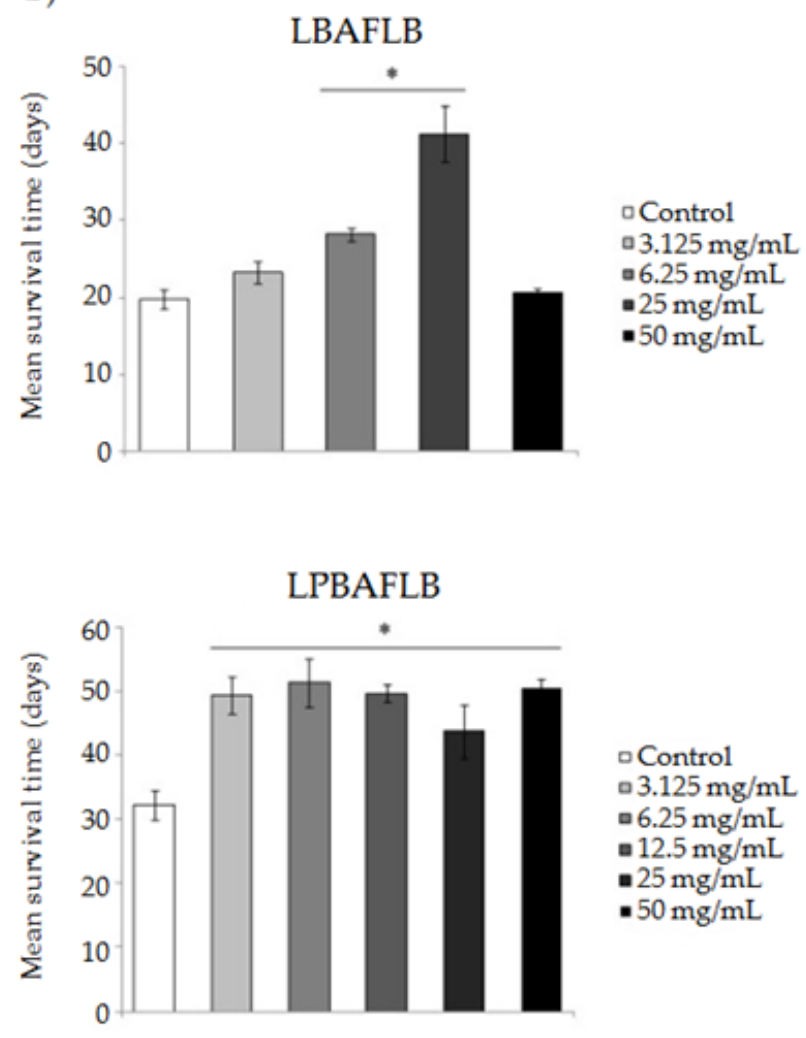

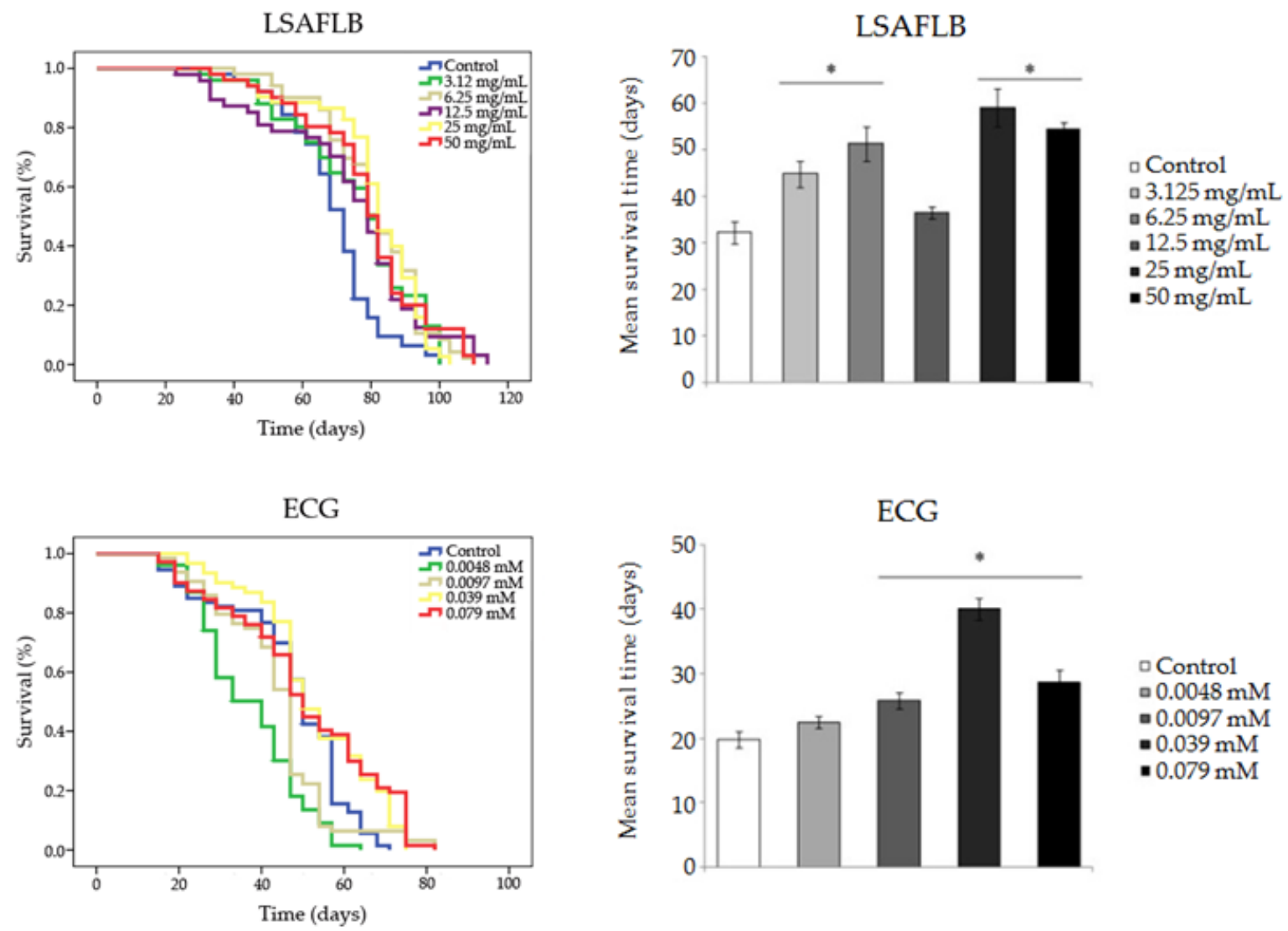

Figure 3. Survival parameters of $D$. melanogaster fed with different concentrations of lyophilised blond alcohol-free lager beer (LBAFLB), lyophilised pale-blond alcohol-free lager beer (LPBAFLB), lyophilised stout alcohol-free lager beer (LSAFLB) and epicatechin gallate (ECG). (A) Survival curves and (B) healthspan averages. (A) Survival curves of D. melanogaster. (B) Mean of survival time in the highest $75 \%$ of surviving population. * indicates significant differences $(p<0.001)$ compared to the control.

In reference to the healthspan results, all tested compounds showed the ability to improve the quality of life of flies, compared to their corresponding control, at some concentrations tested. LBAFLB produced a significant improvement of healthspan in $D$. melanogaster compared to the control in the two central concentrations assayed (6.25 and $12.5 \mathrm{mg} / \mathrm{mL}$ ) with an increase of 9 and 22 days, respectively. LPBAFLB showed a significant improvement of healthspan at all the assayed concentrations with an average range of 11-19 days with respect to the control. LSAFLB induced a significant improvement of quality of life in Drosophila at all assayed concentrations except at the middle concentration $(12.5 \mathrm{mg} / \mathrm{mL})$ with a range of 12-27 days, compared to the control. ECG exhibited an improvement of healthspan at the three highest concentrations $(0.0097,0.039$ and $0.079 \mathrm{mM})$ with an increase of 6,20 and 9 days, respectively, compared to the control.

Most of the protective properties in beers have been shown to be related with the antioxidant activity of their phenols [61,62]. Arimoto-Kobayashi et al. [63] evaluated the antigenotoxic potential of beer components against carcinogens contained in the human diet, suggesting their protective capacity. Moreover, the formation of the Maillard intermediate is correlated with the alcohol content and colour [64,65]. Studies with coloured final products of the Maillard reaction, which were formed non-enzymatically during the roasting of malt, indicate peroxyl radical scavenging potential [66]. This fact, along with the presence of other phenols, could be the responsible for the stronger antitoxic potential of LSAFLB at the lowest concentration. Moreover, our results are in agreement with findings 
about the antioxidant ability of blond and stout beers found by Tafulo et al. [67], Granato et al. [15] and Merinas-Amo et al. [7].

Table 4. Mean and significancy of curves for lifespan and healthspan.

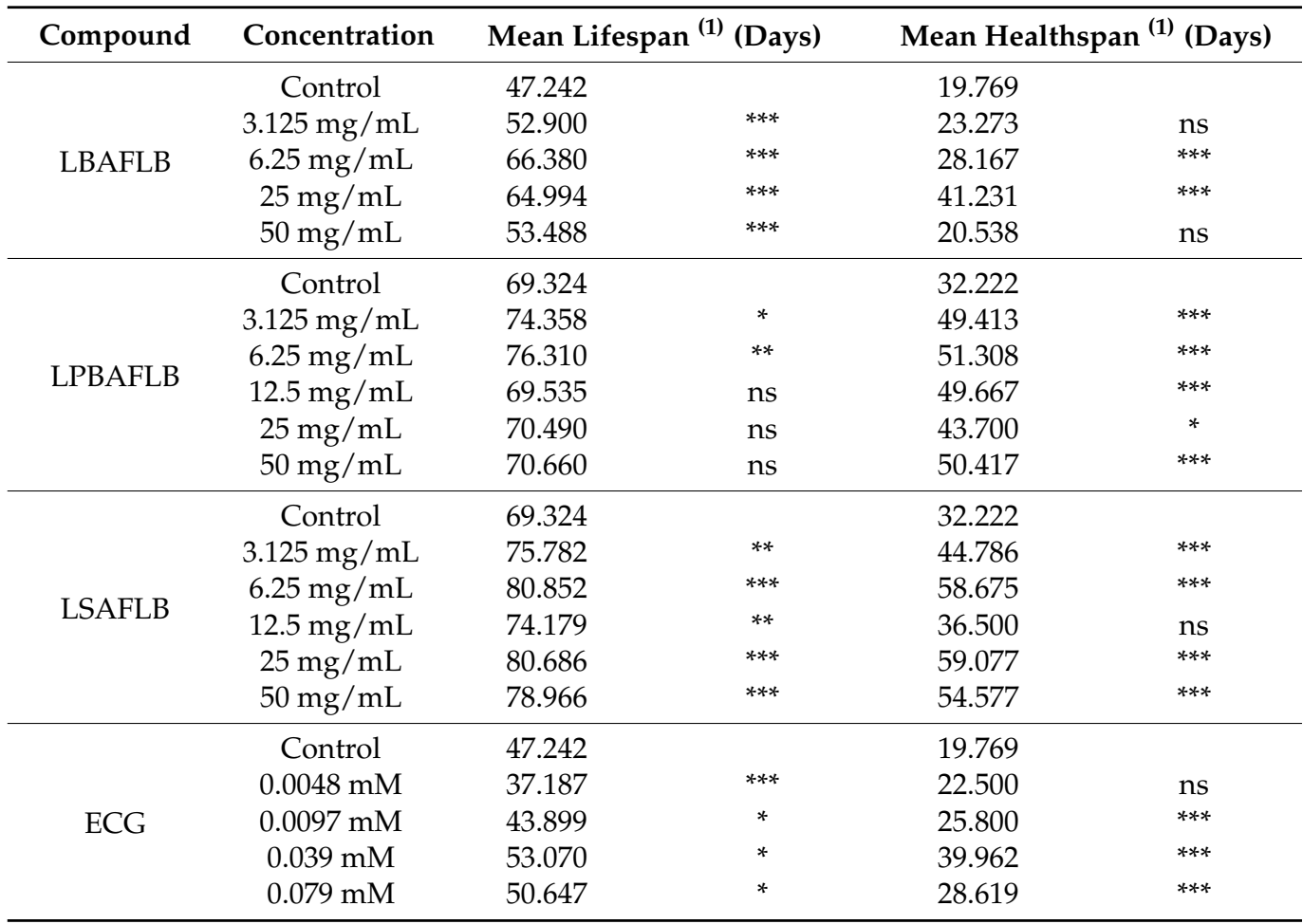

Means were calculated by the Kaplan-Meier method and significance of the curves were determined by the log-rank method (Mantel-Cox). ${ }^{(1)}$ ns: non-significant $(p>0.05),{ }^{*}$ : significant $(p<0.05),{ }^{* *}$ : highly significant $(p<0.01),{ }^{* * *}$ : very highly significant $(p<0.001)$.

Research confirms the antioxidant effect showed by ECG as it act as a scavenger of free radicals and suppressor of oxidative stress [68,69]. Therefore, and due to their polyphenols content, beers could be a source of bioactive compounds with suitable freeradical scavenging properties, such as isoxanthohumol, ferulic acid, vanillic, folic acid and choline, among others [7,70-73].

The alcoholic lyophilised blond lager beer induced an increase in lifespan in $D$. melanogaster ranging between 55.3 and 64.9 days compared to the control [7]. Moreover, the healthspan was significantly increased in the reference compared to the control, except for the highest concentration $(50 \mathrm{mg} / \mathrm{mL})$. We speculate that the antioxidant components of beer neutralise the oxidative radicals originated during the metabolism of the rest of the diet in the Drosophila longevity trials by increasing life and healthspan.

Studies about the important effects of ECG in the inhibition of the development of insulin resistance and hyperglycaemia [74], coronary disease and atherogenesis [75] and its role in obesity as a therapeutic substance [76-78] confirm the positive properties that this phenol exhibited. Moreover, Gorinstein et al. [79] and Gorinstein et al. [80] reported a beneficial effect of a special type of beer with an epicatechin content of $132 \pm 2.5 \mathrm{mg} / \mathrm{mL}$ on some blood parameters. In addition, age-associated diseases such as Parkinson disease were inhibited by ECG intake [81,82]. Our results agree with the health effects that beer and ECG have exhibited. Furthermore, the role of ECG was studied on Drosophila in order to analyse its effect on neurons that are also present in humans (climbing ability, lipid peroxidation and apoptosis in the brain of flies) obtaining a promising effect when the phenol was supplemented at concentrations of $0.25,0.50$ and $1.0 \mu \mathrm{g} / \mathrm{mL}$ [69]. Our results agree with these findings. Moreover, we could relate the beneficial properties of the phenols with the safety and protective effects of the AFBs. 


\subsection{Chemoprotection: Cytotoxicity and DNA Damage}

All substances assayed showed cytotoxic activity against HL-60 cells (Figure 4). LBAFLB showed an increase in the cytotoxicity level according to the increased concentration of the tested compound, being the inhibitory concentration $50\left(\mathrm{IC}_{50}\right) 7.81 \mathrm{mg} / \mathrm{mL}$. LPBAFLB and LSAFLB showed a stronger chemopreventive activity, inducing inhibitory tumour cells' total growth at $31.25 \mathrm{mg} / \mathrm{mL}$ and reached the $\mathrm{IC}_{50}$ value of over $0.488 \mathrm{mg} / \mathrm{mL}$. Finally, the cytotoxicity of ECG exerted a progressive dose-dependent inhibition of cell growth, reaching the $\mathrm{IC}_{50}$ value at the medium concentration tested $(0.0195 \mathrm{mM})$.

A)
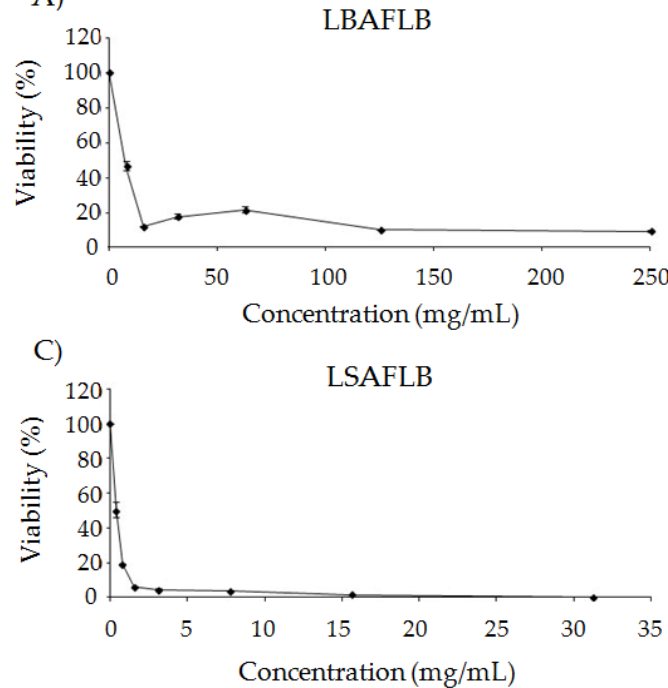

B)

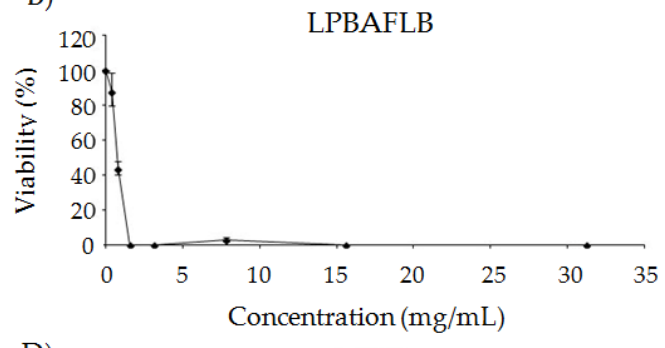

D)

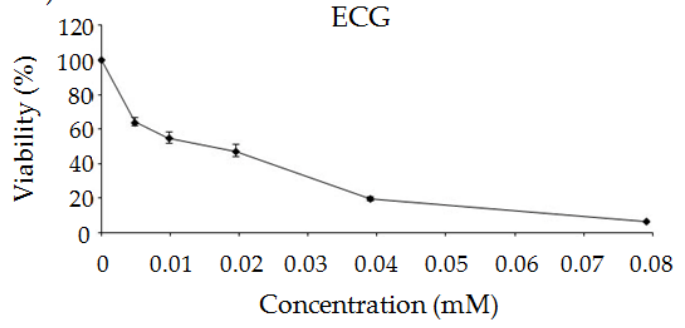

Figure 4. Effect of lyophilised blond alcohol-free lager beer (LBAFLB), lyophilised pale-blond alcoholfree lager beer (LPBAFLB), lyophilised stout alcohol-free lager beer (LSAFLB) and epicatechin gallate (ECG) on cell viability. Viability in promyelocytic human leukaemia cells (HL-60) treated with different concentrations of LBAFLB (A), LPBAFLB (B), LSAFLB (C) and ECG (D) for $72 \mathrm{~h}$. Each point represents the growing percentage compared to its control. Values are mean +/ - SE from three independent experiments.

There are contradictory reports with regard to the relationship between beer consumption and cancer risk. Riboli et al. [83] demonstrated that beer consumption is not related with colon cancer; contrarily, Kato et al. [84] showed that beer drinkers have an increased risk of colorectal cancer, and a connection between beer consumption and lung cancer was suggested by Potter et al. [85]. Nevertheless, an inverse connection between moderate beer consumption and endometrial cancer was proposed by Swanson et al. [86]. In vitro studies have demonstrated the anti-proliferative activity of lager beer components with antioxidant properties in prostate cancer cells and HL-60 promyelocytic cancer cells, showing a firm connection among antioxidant potency, polyphenols content and antiproliferative activity $[7,87]$. The present cytotoxic results of the different AFBs are supported by the epidemiological data on the safety and the in vitro results of lager beer. Several studies supported the beneficial effects of ECG in chemoprevention. In animal model studies, ECG was able to inhibit growth tumours in the colon [88-90], breast [91,92], prostate [93,94], head and neck [95], lung [96] and skin [93,97], and has several other biological effects on human diseases. Our results agree with the chemopreventive potential of ECG against tumour cells' growth. Moreover, we could hypothesise that ECG is a chemopreventive element found in alcohol-free beers.

The DNA damage of tumour cells treated with different concentrations of our assayed compounds was evaluated by DNA internucleosomal fragmentation and DNA strand break induction (Figure 5) and modification in the DNA methylation status of the HL-60 cells (Figure 6). DNA internucleosomal fragmentation is represented by a DNA laddering, and it is related with the activation of the apoptotic way in cancer cells. DNA breaks were 
observed in the three lowest concentrations of LBAFLB $(15.625,31.25$ and $62.5 \mathrm{mg} / \mathrm{mL})$ and in the two lowest concentrations of LPBAFLB and LSAFLB (15.625 and $31.25 \mathrm{mg} / \mathrm{mL})$. On the other hand, ECG did not induce internucleosomal fragmentation at any assayed concentrations (Figure 5). These results do not allow us to establish any relation between ECG effects and the properties showed by the alcohol-free beers to induce DNA fragmentation. That fact could be due to the presence of other compounds that give the final properties to the AFBs. In a study with a blond alcoholic beer, Merinas-Amo et al. [7] related the property of beer to induce proapoptotic DNA fragmentation with the presence of xanthohumol.

The comet assay technique allowed us to readily identify, at a unicellular level, apoptotic nuclei based on the typical morphological changes attributable to extensive DNA damage [98]. Based on the work of Fabiani et al. [99], the frequency distribution of DNA damage can be categorised into five classes according to the TM values as follows: class 0 (TM < 1; no damage), class 1 (TM 1-5; slightly damaged), class 2 (TM 5-10; medium damage), class 3 (TM 10-20; highly damaged) and class 4 (TM >20; completely damaged). Based on this categorisation, all control values fell into class $0(\mathrm{TM}<1)$; LBAFLB 31.25 and $62.25 \mathrm{mg} / \mathrm{mL}$ showed a TM value near to 100, which indicated the induction of high and complete clastogenicity damage in HL-60 cells; the same properties were shown by LPBAFLB, which induced significant damage at the $62.5 \mathrm{mg} / \mathrm{mL}$ concentration with a TM value higher than 20; LSAFLB showed slight damage at the two lowest concentrations assayed (15.625 and $31.25 \mathrm{mg} / \mathrm{mL}$ ) with a TM value lower than 5, and included high damage at the highest concentration (TM < 20); ECG induced TM values over 3 (class 1) at 0.0048 and $0.0195 \mathrm{mM}$, which resulted in slight damage to cells (Figure 5). Although ECG induced slight DNA damage $(\mathrm{TM}<5)$, it was not responsible for the high damage induced by alcohol-free beers (TM $>100$ and TM $>20)$. That fact could be because of the presence of other compounds that give the final properties of AFBs.

Regarding the relative normalised expression of the three repetitive sequences (Alu M1, LINE-1 and Sat- $\alpha$ ) studied in HL-60 cells treated with different concentrations of our compounds (Figure 6), the following observations were made: LBAFLB showed a significant hypomethylated status at the highest concentration tested $(250 \mathrm{mg} / \mathrm{mL})$ for Alu M1 and at both concentrations tested $(15.625$ and $250 \mathrm{mg} / \mathrm{mL})$ for the LINE-1 repetitive sequence, compared to the corresponding control; LPBAFLB showed significant hypermethylation in $15.625 \mathrm{mg} / \mathrm{mL}$ treatments on Alu M1 and Sat- $\alpha$ repetitive sequences and hypomethylation at the highest concentration $(250 \mathrm{mg} / \mathrm{mL})$ for the LINE-1 sequence, compared to their controls; contrarily, LSAFLB showed a hypermethylation in the $250 \mathrm{mg} / \mathrm{mL}$ treatment for all the repetitive sequences and hypomethylation at the lowest concentration (15.625 mg/mL) for the LINE-1 sequence; ECG showed a general tendency towards methylate leukaemia cells with significant hypermethylation at 0.0048 and $0.079 \mathrm{mM}$ for Alu M1 and only $0.079 \mathrm{mM}$ for Sat- $\alpha$ sequences, compared to their controls.

To our knowledge, all previous studies on AFBs have been carried out in order to analyse the DNA fragmentation pattern that this beer causes in cancer cells. Studies with blond lager beer showed a fragmentation effect at the two lowest concentrations of the beer $(15.625$ and $31.25 \mathrm{mg} / \mathrm{mL})$ and a slight effect at the intermediate concentration $(62.5 \mathrm{mg} / \mathrm{mL})$ [7], the findings of which are in agreement with our results. Treatment with ECG in different tumour cells such as human epidermis carcinoma (A431), human carcinoma karatinocyte (HaCaT), human prostate carcinoma (DU145), mouse lymphoma (L5178Y) and human oral tumour cells (HSC-2) induced apoptosis by induction of DNA fragmentation, but this was not the case in normal NHEK cells or HGF-2 fibroblasts [93,100]. Our results do not agree with these previous findings, most likely because we studied lower concentrations than the $40 \mu \mathrm{g} / \mathrm{mL}$ dose used by the previous authors. 
A)

LBAFLB $\quad(\mathrm{mg} / \mathrm{mL})$

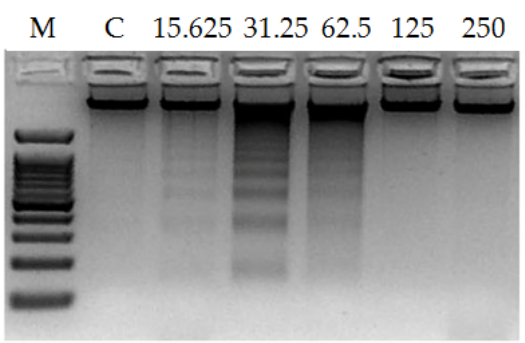

LPBAFLB $\quad(\mathrm{mg} / \mathrm{mL})$

M $\quad$ C $15.62531 .2562 .5125 \quad 250$

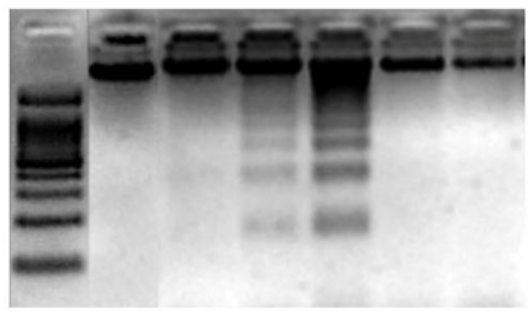

LSAFLB $\quad(\mathrm{mg} / \mathrm{mL})$

M C $\quad 15.62531 .2562 .5125 \quad 250$

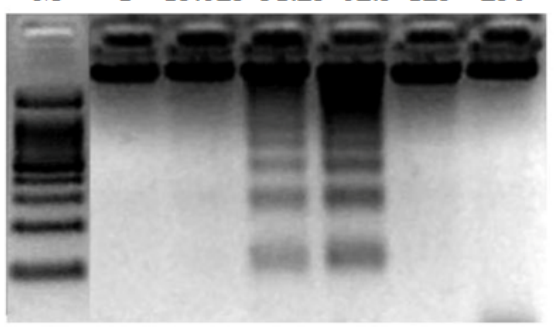

ECG $(\mathrm{mM})^{(1)}$

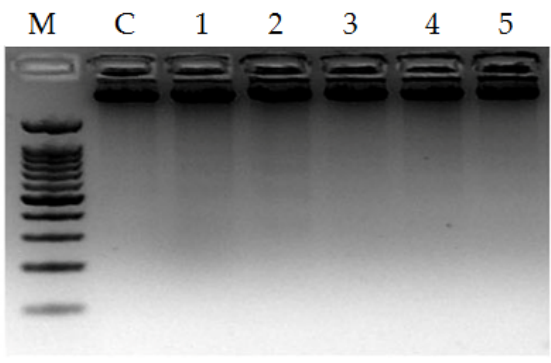

B)
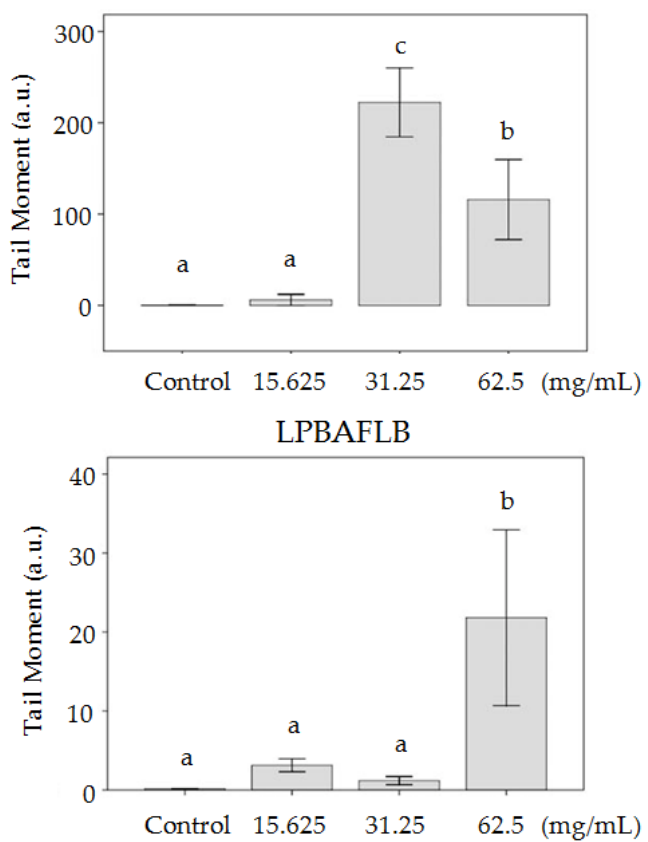

LSAFLB

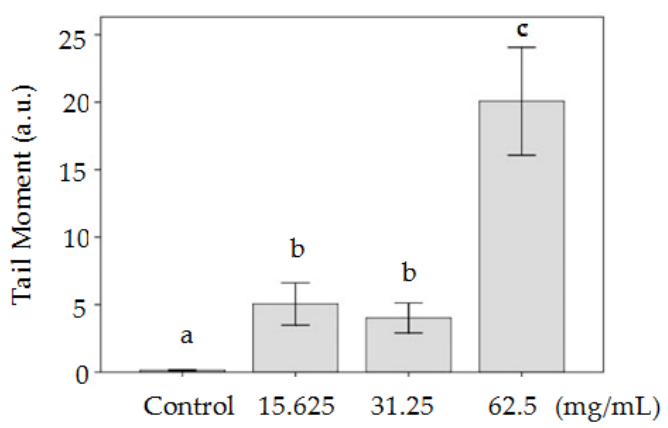

ECG

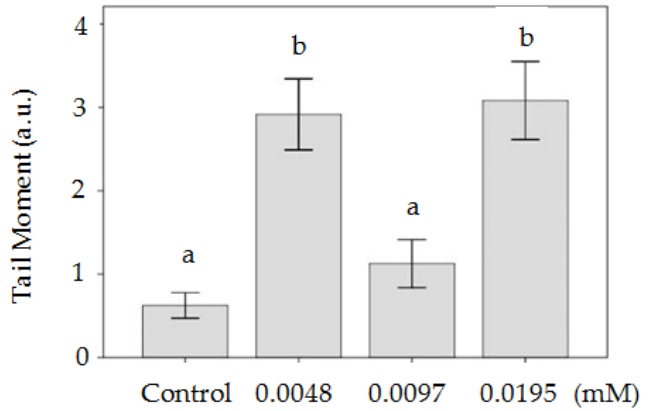

Figure 5. DNA-induced damage in promyelocytic HL-60 cells treated with different concentrations of lyophilised blond alcohol-free lager beer (LBAFLB), lyophilised pale-blond alcohol-free lager beer (LPBAFLB), lyophilised stout alcohol-free lager beer (LSAFLB) and epicatechin gallate (ECG) for $5 \mathrm{~h}$. (A) Internucleosomal DNA fragmentation. (B) DNA strand break induction. (A) M indicates DNA size marker, $C$ indicates control treatment. ${ }^{(1)}$ ECG: concentrations of $0.0048 \mathrm{mM}(1), 0.0097 \mathrm{mM}(2)$, $0.0195 \mathrm{mM}(3), 0.039 \mathrm{mM}(4)$ and $0.079 \mathrm{mM}$ (5). (B) Alkaline comet assay ( $\mathrm{pH}<13)$ of HL-60 cells treated. DNA migrations are reported as mean TM. Values are mean $+/-$ SE. Different letters $(b$ and c) in treatment indicate differences compared to the negative control (a) after one-way ANOVA and post hoc Tukey's test. 
A)

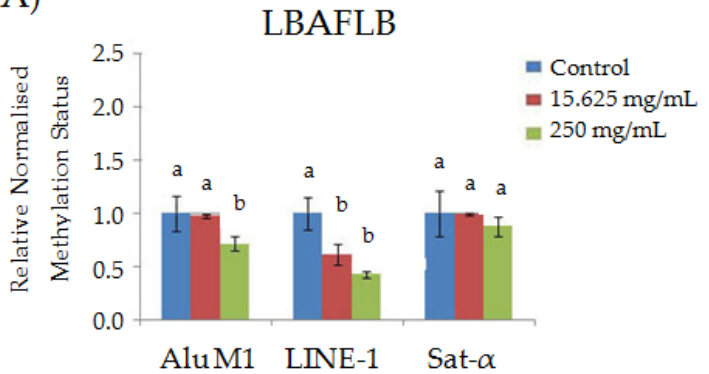

C)

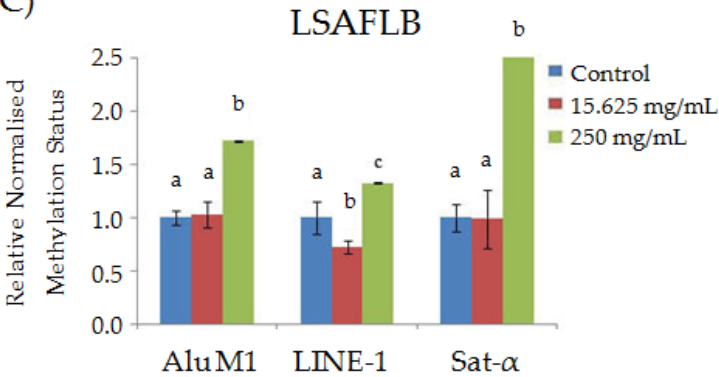

B)

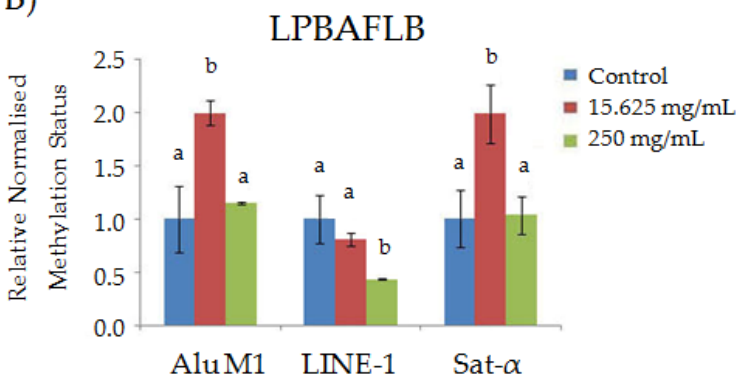

D)

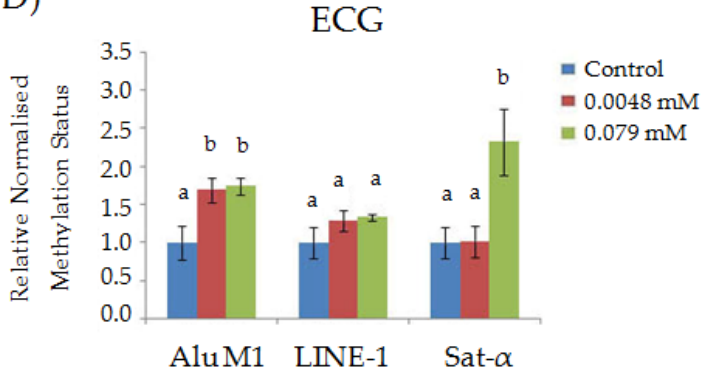

Figure 6. Relative normalised expression data of each repetitive element in treated HL-60 cells with different concentration of lyophilised blond alcohol-free lager beer (LBAFLB) (A), lyophilised pale-blond alcohol-free lager beer (LPBAFLB) (B), lyophilised stout alcohol-free lager beer (LSAFLB) (C) and epicatechin gallate (ECG) (D). The different letters ( $a, b$ and c) in each compound and each repetitive element indicate differences compared to the negative control (a) (ANOVA followed by post hoc Tukey's test).

TM values have been shown to be correlated with cytotoxicity ones [101]. Our results agree with that relation, showing significant TM values in agreement with the viability percentage of HL-60 cells. Moreover, the results of DNA fragmentation are in line with those obtained in comet assays, considering that TM values higher than 30 indicate an induction of apoptosis mechanisms [102]. Only the two highest concentrations of LBAFLB assayed showed TM > 30, supporting the death of leukaemia cells by apoptosis. The rest of the compounds and concentrations tested induced cell death by a necrosis mechanism.

The procedure of controlling epigenetic DNA modifications is complex [103]. Endoparasitic repetitive sequences refrain from jumping around due to the repression of DNA methylation [104]. The majority of DNA methylation in humans takes place in the cytosine of $\mathrm{CpG}$ dinucleotides (CpG islands). In an ordinary cell, they are unmethylated, and the gene is expressed if the needed transcription factors are present [104]. As a result of the methylation effects caused in the repetitive sequences of the genome and understanding the methylation of repetitive sequences as a genomic protective mechanism [55,105], we could say that only LPBAFLB has an effect on Alu M1 and Sat- $\alpha$ at the lowest concentrations; LSAFLB at the highest concentrations for all repetitive sequences studied; and ECG at the lowest concentration for Alu M1 and Sat- $\alpha$ and the highest concentration for Alu M1 sequences, which prevents DNA epigenetic damages. Besides that, and taking into account the idea of tumour cells' demethylation, this would indicate that beers and their compounds act as preventive agents, cutting off the repetitive sequences of tumour cells [105].

Unfortunately, no previous studies related with the methylation status induced by AFBs or ECG were found. Merinas-Amo et al. [7] proved that a lyophilised blond lager beer cause an increase in the DNA methylation level in treated tumour cells in different repetitive sequences. Fang et al. [106] proposed that in conventional dietary consumption the effect of a single polyphenol is not significant, while in contrast the combination of polyphenols with dietary histone deacetylase inhibitors and the additive effect of different dietary chemicals 
may produce some effects. Furthermore, the extreme consumption of polyphenols in dietary supplements could affect the DNA methylation status [106]. Consequently, single or combined phenols included in food should be taken into consideration in epigeneticfocused therapies as not everything is worthy.

\section{Conclusions}

The different compositions and brewing processes of drinks could influence the final outcomes of the full beer. Although further research must be carried out to check the properties of alcohol-free beers in other animal models and even in humans, the results of in vivo and in vitro studies with model organisms (animal and cell) are promising.

Results suggest the safety properties of all compounds, although LPBAFLB and LSAFLB showed a genotoxic activity only at the lowest concentrations assayed. Moreover, all the studied alcohol-free beers and ECG were able to protect against $\mathrm{H}_{2} \mathrm{O}_{2}$ oxidative damage as well as to induce an increase in longevity with an improvement of the quality of life in the in vivo animal model assayed. Promising results were obtained with the alcoholfree beers and ECG in the in vitro assays with human leukaemia cells as they inhibited the tumour cells' growth, induced DNA damage and modified the methylation status of such a cancer cell line.

Taking into account the ideas introduced and results obtained in the present work, we could suggest that alcohol-free beers should be of interest not only because of their reduced calories and isotonic properties but also their recognised potential as nutraceutical substances due to their safety and protective and chemopreventive elements, as presented herein.

Author Contributions: Conceptualization, Á.A.-M. and M.D.R.C.; methodology, T.M.-A.; formal analysis, T.M.-A.; investigation, Á.A.-M., M.D.R.C. and R.F.; writing-original draft preparation, T.M.-A.; writing-review and editing, Á.A.-M., M.D.R.C. and R.F. All authors have read and agreed to the published version of the manuscript.

Funding: No external funding was received.

Institutional Review Board Statement: Not applicable.

Informed Consent Statement: Not applicable.

Data Availability Statement: The data presented in this study are available from the corresponding author on reasonable request.

Conflicts of Interest: The authors declare no conflict of interest.

\section{References}

1. Muller, R.; Walker, S.; Brauer, J.; Junquera, M. Does beer contain compounds that might interfere with cholesterol metabolism? J. Inst. Brew. 2007, 113, 102-109. [CrossRef]

2. Bassus, S.; Mahnel, R.; Scholz, T.; Wegert, W.; Westrup, D.; Kirchmaier, C.M. Effect of dealcoholized beer (Bitburger Drive) consumption on hemostasis in humans. Alcohol. Clin. Exp. Res. 2004, 28, 786-791. [CrossRef] [PubMed]

3. Chen, W.; Becker, T.; Qian, F.; Ring, J. Beer and beer compounds: Physiological effects on skin health. J. Eur. Acad. Derm. Venereol. 2013, 28, 142-150. [CrossRef] [PubMed]

4. Piazzon, A.; Forte, M.; Nardini, M. Characterization of phenolics content and antioxidant activity of different beer types. J. Agric. Food Chem. 2010, 58, 10677-10683. [CrossRef] [PubMed]

5. Hornsey, I.S. A History of Beer and Brewing; Royal Society of Chemistry: London, UK, 2003; Volume 34.

6. Gerhäuser, C. Beer constituents as potential cancer chemopreventive agents. Eur. J. Cancer 2005, 41, 1941-1954. [CrossRef]

7. Merinas-Amo, T.; Tasset-Cuevas, I.; Díaz-Carretero, A.M.; Alonso-Moraga, Á.; Calahorro, F. In vivo and in vitro studies of the role of lyophilised blond Lager beer and some bioactive components in the modulation of degenerative processes. J. Funct. Foods 2016, 27, 274-294. [CrossRef]

8. Merinas-Amo, T.; Merinas-Amo, R.; Font, R.; del Río Celestino, M.; Alonso-Moraga, Á. Toxicological and Epigenetic Studies of Two Types of Ale Beer, Tyrosol and Iso-Alpha Humulone. Processes 2021, 9, 485. [CrossRef]

9. Stevens, J.F.; Miranda, C.L.; Wolthers, K.R.; Schimerlik, M.; Deinzer, M.L.; Buhler, D.R. Identification and in vitro biological activities of hop proanthocyanidins: Inhibition of nNOS activity and scavenging of reactive nitrogen species. J. Agric. Food Chem. 2002, 50, 3435-3443. [CrossRef] 
10. Gerhäuser, C.; Becker, H. Phenolic compounds in beer. In Beer in Health and Disease Prevention; Elsevier: London, UK, 2009; pp. 124-144.

11. Cui, L.; Liu, Y.; Liu, T.; Yuan, Y.; Yue, T.; Cai, R.; Wang, Z. Extraction of Epigallocatechin Gallate and Epicatechin Gallate from Tea Leaves Using $\beta$-Cyclodextrin. J. Food Sci. 2017, 82, 394-400. [CrossRef]

12. Zaveri, N.T. Green tea and its polyphenolic catechins: Medicinal uses in cancer and noncancer applications. Life Sci. 2006, 78, 2073-2080. [CrossRef]

13. Bartolomé, B.; Pena-Neira, A.; Gómez-Cordovés, C. Phenolics and related substances in alcohol-free beers. Eur. Food Res. Technol. 2000, 210, 419-423. [CrossRef]

14. McMurrough, I.; Baert, T. Identification of proanthocyanidins in beer and their direct measurement with a dual electrode electrochemical detector. J. Inst. Brew. 1994, 100, 409-416. [CrossRef]

15. Granato, D.; Branco, G.F.; Faria, J.d.A.F.; Cruz, A.G. Characterization of Brazilian lager and brown ale beers based on color phenolic compounds, and antioxidant activity using chemometrics. J. Sci. Food Agric. 2011, 91, 563-571. [CrossRef]

16. De Keukeleire, D. Fundamentals of beer and hop chemistry. Quim. Nova 2000, 23, 108-112. [CrossRef]

17. Kodama, Y.; Kielland-Brandt, M.C.; Hansen, J. Lager brewing yeast. In Comparative Genomics; Springer: Berlin/Heidelberg, Germany, 2006; pp. 145-164.

18. Cantrell, I.; Griggs, D. Malt: Its role in oxidation. Tech. Q.-Master Brew. Assoc. Am. 1996, 33, 82-86.

19. Woffenden, H.M.; Ames, J.M.; Chandra, S. Relationships between antioxidant activity, color, and flavor compounds of crystal malt extracts. J. Agric. Food Chem. 2001, 49, 5524-5530. [CrossRef] [PubMed]

20. Coghe, S.; Vanderhaegen, B.; Pelgrims, B.; Basteyns, A.-V.; Delvaux, F.R. Characterization of dark specialty malts: New insights in color evaluation and pro-and antioxidative activity. J. Am. Soc. Brew. Chem. 2003, 61, 125-132. [CrossRef]

21. Brányik, T.; Silva, D.P.; Baszczyňski, M.; Lehnert, R.; e Silva, J.B.A. A review of methods of low alcohol and alcohol-free beer production. J. Food Eng. 2012, 108, 493-506. [CrossRef]

22. Etuk, B.; Murray, K. Mechanism for the removal of alcohol from beer by emulsion liquid membranes. Food Bioprod. Processing $1991,69,27-34$

23. Matson, S.L. Production of Low-Ethanol Beverages by Membrane Extraction. Patent WO1987002380, 30 June 1988.

24. Anglerot, D. Process of Making Alcohol-Free Beer and Beer Aroma Concentrates. U.S. Patent US5308631A, 3 May 1994.

25. Von Hodenberg, G. Production of alcoholfree beers using reverse osmosis. Brauwelt Int. (Ger. F.R.) 1991, 2, 145-149.

26. Richardson, H.E.; Willoughby, L.; Humbert, P.O. Screening for Anti-cancer Drugs in Drosophila. eLS 2015, 2, 97-103.

27. Graf, U.; Wurgler, F.E.; Katz, A.J.; Frei, H.; Juon, H.; Hall, C.B.; Kale, P.G. Somatic mutation and recombination test in Drosophila melanogaster. Environ. Mutagenesis 1984, 6, 153-188. [CrossRef] [PubMed]

28. De Gaetano, G.; Costanzo, S.; Di Castelnuovo, A.; Badimon, L.; Bejko, D.; Alkerwi, A.a.; Chiva-Blanch, G.; Estruch, R.; La Vecchia, C.; Panico, S. Effects of moderate beer consumption on health and disease: A consensus document. Nutr. Metab. Cardiovasc. Dis. 2016, 26, 443-467. [CrossRef] [PubMed]

29. Pavsler, A.; Buiatti, S. Lager beer. In Beer in Health and Disease Prevention; Elsevier: Amsterdam, The Netherlands, 2009 ; pp. 31-43.

30. Kirin. Globar Beer Consumption by Country in 2011. Available online: https://www.kirinholdings.com/en/newsroom/release/ 2019/1224_01.html (accessed on 24 December 2019).

31. Ja, W.W.; Carvalho, G.B.; Mak, E.M.; de la Rosa, N.N.; Fang, A.Y.; Liong, J.C.; Brummel, T.; Benzer, S. Prandiology of Drosophila and the CAFE assay. Proc. Natl. Acad. Sci. USA 2007, 104, 8253-8256. [CrossRef]

32. Bier, E. Drosophila, the golden bug, emerges as a tool for human genetics. Nat. Rev. Genet. 2005, 6, 9-23. [CrossRef]

33. Lloyd, T.E.; Taylor, J.P. Flightless flies: Drosophila models of neuromuscular disease. Ann. N. Y. Acad. Sci. 2010, 1184, E1-E20. [CrossRef]

34. Bhargav, D.; Singh, M.P.; Murthy, R.C.; Mathur, N.; Misra, D.; Saxena, D.K.; Chowdhuri, D.K. Toxic potential of municipal solid waste leachates in transgenic Drosophila melanogaster (hsp70-lacZ): Hsp70 as a marker of cellular damage. Ecotoxicol. Environ. Saf. 2008, 69, 233-245. [CrossRef]

35. Coulom, H.; Birman, S. Chronic exposure to rotenone models sporadic Parkinson's disease in Drosophila melanogaster. J. Neurosci. 2004, 24, 10993-10998. [CrossRef]

36. Dean, B.J. Recent findings on the genetic toxicology of benzene, toluene, xylenes and phenols. Mutat. Res./Rev. Genet. Toxicol. 1985, 154, 153-181. [CrossRef]

37. Hosamani, R. Acute exposure of Drosophila melanogaster to paraquat causes oxidative stress and mitochondrial dysfunction. Arch. Insect Biochem. Physiol. 2013, 83, 25-40. [CrossRef]

38. Siddique, Y.H.; Fatima, A.; Jyoti, S.; Naz, F.; Khan, W.; Singh, B.R.; Naqvi, A.H. Evaluation of the toxic potential of graphene copper nanocomposite (GCNC) in the third instar larvae of transgenic Drosophila melanogaster (hsp70-lacZ) Bg 9. PLoS ONE 2013, 8, e80944. [CrossRef] [PubMed]

39. Yan, J.; Huen, D.; Morely, T.; Johnson, G.; Gubb, D.; Roote, J.; Adler, P.N. The multiple-wing-hairs gene encodes a novel GBD-FH3 domain-containing protein that functions both prior to and after wing hair initiation. Genetics 2008, 180, 219-228. [CrossRef] [PubMed]

40. Ren, N.; Charlton, J.; Adler, P.N. The flare gene, which encodes the AIP1 protein of Drosophila, functions to regulate F-actin disassembly in pupal epidermal cells. Genetics 2007, 176, 2223-2234. [CrossRef] [PubMed] 
41. Collins, S.J. The HL-60 promyelocytic leukemia cell line: Proliferation, differentiation, and cellular oncogene expression. Blood 1987, 70, 1233-1244. [CrossRef] [PubMed]

42. Gallagher, R.; Collins, S.; Trujillo, J.; McCredie, K.; Ahearn, M.; Tsai, S.; Metzgar, R.; Aulakh, G.; Ting, R.; Ruscetti, F.; et al. Characterization of the continuous, differentiating myeloid cell line (HL-60) from a patient with acute promyelocytic leukemia. Blood 1979, 54, 713-733. [CrossRef]

43. Frei, H.; Wurgler, F.E. Statistical methods to decide whether mutagenicity test data from Drosophila assays indicate a positive, negative, or inconclusive result. Mutat. Res. 1988, 203, 297-308. [CrossRef]

44. Frei, H.; Wurgler, F.E. Optimal experimental design and sample size for the statistical evaluation of data from somatic mutation and recombination tests (SMART) in Drosophila. Mutat. Res. 1995, 334, 247-258. [CrossRef]

45. Valadares, B.; Graf, U.; Spanó, M. Inhibitory effects of water extract of propolis on doxorubicin-induced somatic mutation and recombination in Drosophila melanogaster. Food Chem. Toxicol. 2008, 46, 1103-1110. [CrossRef]

46. Tasset-Cuevas, I.; Fernandez-Bedmar, Z.; Lozano-Baena, M.D.; Campos-Sanchez, J.; de Haro-Bailon, A.; Munoz-Serrano, A.; Alonso-Moraga, A. Protective effect of borage seed oil and gamma linolenic acid on DNA: In vivo and in vitro studies. PLoS ONE 2013, 8, e56986. [CrossRef]

47. Graf, U.; Abraham, S.K.; Guzman-Rincon, J.; Wurgler, F.E. Antigenotoxicity studies in Drosophila melanogaster. Mutat. Res. 1998, 402, 203-209. [CrossRef]

48. Abraham, S.K. Antigenotoxicity of coffee in the Drosophila assay for somatic mutation and recombination. Mutagenesis 1994, 9 , 383-386. [CrossRef] [PubMed]

49. Soh, J.W.; Hotic, S.; Arking, R. Dietary restriction in Drosophila is dependent on mitochondrial efficiency and constrained by pre-existing extended longevity. Mech. Ageing Dev. 2007, 128, 581-593. [CrossRef] [PubMed]

50. Mateo-Fernández, M.; Merinas-Amo, T.; Moreno-Millán, M.; Alonso-Moraga, Á.; Demyda-Peyrás, S. In vivo and in vitro genotoxic and epigenetic effects of two types of cola beverages and caffeine: A multi-assay approach. BioMed Res. Int. 2016, 2016, 15. [CrossRef] [PubMed]

51. Deininger, P.L.; Moran, J.V.; Batzer, M.A.; Kazazian, H.H., Jr. Mobile elements and mammalian genome evolution. Curr. Opin. Genet. Dev. 2003, 13, 651-658. [CrossRef] [PubMed]

52. Lee, C.; Wevrick, R.; Fisher, R.B.; Ferguson-Smith, M.A.; Lin, C.C. Human centromeric DNAs. Hum. Genet. 1997, 100, 291-304. [CrossRef] [PubMed]

53. Ehrlich, M. DNA methylation in cancer: Too much, but also too little. Oncogene 2002, 21, 5400-5413. [CrossRef] [PubMed]

54. Weiner, A.M. SINEs and LINEs: The art of biting the hand that feeds you. Curr. Opin. Cell Biol. 2002, 14, 343-350. [CrossRef]

55. Weisenberger, D.J.; Campan, M.; Long, T.I.; Kim, M.; Woods, C.; Fiala, E.; Ehrlich, M.; Laird, P.W. Analysis of repetitive element DNA methylation by MethyLight. Nucleic Acids Res. 2005, 33, 6823-6836. [CrossRef]

56. Nikolaidis, G.; Raji, O.Y.; Markopoulou, S.; Gosney, J.R.; Bryan, J.; Warburton, C.; Walshaw, M.; Sheard, J.; Field, J.K.; Liloglou, T. DNA methylation biomarkers offer improved diagnostic efficiency in lung cancer. Cancer Res. 2012, 72, 5692-5701. [CrossRef]

57. Liloglou, T.; Bediaga, N.G.; Brown, B.R.; Field, J.K.; Davies, M.P. Epigenetic biomarkers in lung cancer. Cancer Lett. 2014, 342, 200-212. [CrossRef]

58. Anter, J.; Romero-Jimenez, M.; Fernandez-Bedmar, Z.; Villatoro-Pulido, M.; Analla, M.; Alonso-Moraga, A.; Munoz-Serrano, A Antigenotoxicity, cytotoxicity, and apoptosis induction by apigenin, bisabolol, and protocatechuic acid. J. Med. Food 2011, 14, 276-283. [CrossRef] [PubMed]

59. Romero-Jimenez, M.; Campos-Sanchez, J.; Analla, M.; Munoz-Serrano, A.; Alonso-Moraga, A. Genotoxicity and anti-genotoxicity of some traditional medicinal herbs. Mutat. Res. 2005, 585, 147-155. [CrossRef] [PubMed]

60. Psomiadou, E.; Tsimidou, M. Stability of virgin olive oil. 1. Autoxidation studies. J. Agric. Food Chem. 2002, 50, 716-721. [CrossRef] [PubMed]

61. Anter, J.; Campos-Sanchez, J.; Hamss, R.E.; Rojas-Molina, M.; Munoz-Serrano, A.; Analla, M.; Alonso-Moraga, A. Modulation of genotoxicity by extra-virgin olive oil and some of its distinctive components assessed by use of the Drosophila wing-spot test. Mutat. Res. 2010, 703, 137-142. [CrossRef]

62. Preedy, V.R. Beer in Health and Disease Prevention; Academic Press: London, UK, 2011.

63. Arimoto-Kobayashi, S.; Ishida, R.; Nakai, Y.; Idei, C.; Takata, J.; Takahashi, E.; Okamoto, K.; Negishi, T.; Konuma, T. Inhibitory effects of beer on mutation in the Ames test and DNA adduct formation in mouse organs induced by 2-Amino-1-methyl-6phenylimidazo [4, 5-b] pyridine (PhIP). Biol. Pharm. Bull. 2006, 29, 67-70. [CrossRef]

64. Vanderhaegen, B.; Neven, H.; Verstrepen, K.J.; Delvaux, F.R.; Verachtert, H.; Derdelinckx, G. Influence of the brewing process on furfuryl ethyl ether formation during beer aging. J. Agric. Food Chem. 2004, 52, 6755-6764. [CrossRef]

65. Coghe, S.; Martens, E.; D’Hollander, H.; Dirinck, P.J.; Delvaux, F.R. Sensory and instrumental flavour analysis of wort brewed with dark specialty malts. J. Inst. Brew. 2004, 110, 94-103. [CrossRef]

66. Liégeois, C.; Lermusieau, G.; Collin, S. Measuring antioxidant efficiency of wort, malt, and hops against the 2,2'-azobis (2amidinopropane) dihydrochloride-induced oxidation of an aqueous dispersion of linoleic acid. J. Agric. Food Chem. 2000, 48, 1129-1134. [CrossRef]

67. Tafulo, P.A.R.; Queirós, R.B.; Delerue-Matos, C.M.; Sales, M.G.F. Control and comparison of the antioxidant capacity of beers Food Res. Int. 2010, 43, 1702-1709. [CrossRef] 
68. Rizvi, S.I.; Zaid, M.A.; Anis, R.; Mishra, N. Protective role of tea catechins against oxidation-induced damage of type 2 diabetic erythrocytes. Clin. Exp. Pharmacol. Physiol. 2005, 32, 70-75. [CrossRef]

69. Siddique, Y.H.; Jyoti, S.; Naz, F. Effect of epicatechin gallate dietary supplementation on transgenic Drosophila model of Parkinson's disease. J. Diet. Suppl. 2014, 11, 121-130. [CrossRef] [PubMed]

70. Cuvelier, M.-E.; Richard, H.; Berset, C. Comparison of the antioxidative activity of some acid-phenols: Structure-activity relationship. Biosci. Biotechnol. Biochem. 1992, 56, 324-325. [CrossRef]

71. Srinivasan, M.; Sudheer, A.R.; Menon, V.P. Ferulic acid: Therapeutic potential through its antioxidant property. J. Clin. Biochem. Nutr. 2007, 40, 92-100. [CrossRef] [PubMed]

72. Sánchez-Moreno, C.; Larrauri, J.A.; Saura-Calixto, F. A procedure to measure the antiradical efficiency of polyphenols. J. Sci. Food Agric. 1998, 76, 270-276. [CrossRef]

73. Żołnierczyk, A.K.; Mączka, W.K.; Grabarczyk, M.; Wińska, K.; Woźniak, E.; Anioł, M. Isoxanthohumol—Biologically active hop flavonoid. Fitoterapia 2015, 103, 71-82. [CrossRef] [PubMed]

74. Wu, L.-Y.; Juan, C.-C.; Ho, L.-T.; Hsu, Y.-P.; Hwang, L.S. Effect of green tea supplementation on insulin sensitivity in SpragueDawley rats. J. Agric. Food Chem. 2004, 52, 643-648. [CrossRef]

75. Miura, Y.; Chiba, T.; Miura, S.; Tomita, I.; Umegaki, K.; Ikeda, M.; Tomita, T. Green tea polyphenols (flavan 3-ols) prevent oxidative modification of low density lipoproteins: An ex vivo study in humans. J. Nutr. Biochem. 2000, 11, 216-222. [CrossRef]

76. Kao, Y.-h.; Hiipakka, R.A.; Liao, S. Modulation of obesity by a green tea catechin. Am. J. Clin. Nutr. 2000, 72, 1232-1233. [CrossRef]

77. Tian, W.-X. Inhibition of fatty acid synthase by polyphenols. Curr. Med. Chem. 2006, 13, 967-977. [CrossRef]

78. Zhang, R.; Xiao, W.; Wang, X.; Wu, X.; Tian, W. Novel inhibitors of fatty-acid synthase from green tea (Camellia sinensis Xihu Longjing) with high activity and a new reacting site. Biotechnol. Appl. Biochem. 2006, 43, 1-7.

79. Gorinstein, S.; Zemser, M.; Berliner, M.; Goldstein, R.; Libman, I.; Trakhtenberg, S.; Caspi, A. Moderate beer consumption and positive biochemical changes in patients with coronary atherosclerosis. J. Intern. Med. 1997, 242, 219-224. [CrossRef] [PubMed]

80. Gorinstein, S.; Zemser, M.; Lichman, I.; Berebi, A.; Kleipfish, A.; Libman, I.; Trakhtenberg, S.; Caspi, A. Moderate beer consumption and the blood coagulation in patients with coronary artery disease. J. Intern. Med. 1997, 241, 47-51. [CrossRef] [PubMed]

81. Nie, G.; Jin, C.; Cao, Y.; Shen, S.; Zhao, B. Distinct effects of tea catechins on 6-hydroxydopamine-induced apoptosis in PC12 cells. Arch. Biochem. Biophys. 2002, 397, 84-90. [CrossRef] [PubMed]

82. Mandel, S.; Maor, G.; Youdim, M.B. Iron and $\alpha$-synuclein in the substantia nigra of MPTP-treated mice. J. Mol. Neurosci. 2004, 24, 401-416. [CrossRef]

83. Riboli, E.; Cornée, J.; Macquart-Moulin, G.; Kaaks, R.; Casagrande, C.; Guyader, M. Cancer and polyps of the colorectum and lifetime consumption of beer and other alcoholic beverages. Am. J. Epidemiol. 1991, 134, 157-166. [CrossRef]

84. Kato, I.; Tominaga, S.; Ikari, A. A Case-Control Study of Male Colorectal Cancer in Aichi Prefecture, Japan: With Special Reference to Occupational Activity Level, Drinking Habits and Family History. Jpn. J. Cancer Res. 1990, 81, 115-121. [CrossRef]

85. Potter, J.D.; Sellers, T.A.; Folsom, A.R.; McGovern, P.G. Alcohol, beer, and lung cancer in postmenopausal women the iowa women's health study. Ann. Epidemiol. 1992, 2, 587-595. [CrossRef]

86. Swanson, C.A.; Wilbanks, G.D.; Twiggs, L.B.; Monet, R.; Berman, M.L.; Barrett, R.J.; Brintonl, L.A. Moderate alcohol consumption and the risk of endometrial cancer. Epidemiology 1993, 4, 530-536. [CrossRef]

87. Hevia, D.; Mayo, J.C.; Quiros, I.; Sainz, R.M. Beer constituents inhibit prostate cancer cells proliferation. EJC Suppl. 2008, 6, 142. [CrossRef]

88. Hong, J.; Smith, T.J.; Ho, C.-T.; August, D.A.; Yang, C.S. Effects of purified green and black tea polyphenols on cyclooxygenase-and lipoxygenase-dependent metabolism of arachidonic acid in human colon mucosa and colon tumor tissues. Biochem. Pharmacol. 2001, 62, 1175-1183. [CrossRef]

89. Weyant, M.J.; Carothers, A.M.; Dannenberg, A.J.; Bertagnolli, M.M. (+)-Catechin inhibits intestinal tumor formation and suppresses focal adhesion kinase activation in the min/+ mouse. Cancer Res. 2001, 61, 118-125. [PubMed]

90. Baek, S.J.; Wilson, L.C.; Eling, T.E. Resveratrol enhances the expression of non-steroidal anti-inflammatory drug-activated gene (NAG-1) by increasing the expression of p53. Carcinogenesis 2002, 23, 425-432. [CrossRef] [PubMed]

91. Liao, S.; Umekita, Y.; Guo, J.; Kokontis, J.M.; Hiipakka, R.A. Growth inhibition and regression of human prostate and breast tumors in athymic mice by tea epigallocatechin gallate. Cancer Lett. 1995, 96, 239-243. [CrossRef]

92. Bigelow, R.; Cardelli, J. The green tea catechins,(-)-epigallocatechin-3-gallate (EGCG) and (-)-epicatechin-3-gallate (ECG), inhibit HGF/Met signaling in immortalized and tumorigenic breast epithelial cells. Oncogene 2006, 25, 1922-1930. [CrossRef] [PubMed]

93. Ahmad, N.; Feyes, D.K.; Agarwal, R.; Mukhtar, H.; Nieminen, A.-L. Green tea constituent epigallocatechin-3-gallate and induction of apoptosis and cell cycle arrest in human carcinoma cells. J. Natl. Cancer Inst. 1997, 89, 1881-1886. [CrossRef] [PubMed]

94. Chung, L.; Cheung, T.; Kong, S.; Fung, K.; Choy, Y.; Chan, Z.; Kwok, T. Induction of apoptosis by green tea catechins in human prostate cancer DU145 cells. Life Sci. 2001, 68, 1207-1214. [CrossRef]

95. Lim, Y.C.; Lee, S.-H.; Song, M.H.; Yamaguchi, K.; Yoon, J.-H.; Choi, E.C.; Baek, S.J. Growth inhibition and apoptosis by (-)epicatechin gallate are mediated by cyclin D1 suppression in head and neck squamous carcinoma cells. Eur. J. Cancer 2006, 42, 3260-3266. [CrossRef]

96. Yang, G.-Y.; Liao, J.; Kim, K.; Yurkow, E.J.; Yang, C.S. Inhibition of growth and induction of apoptosis in human cancer cell lines by tea polyphenols. Carcinogenesis 1998, 19, 611-616. [CrossRef] 
97. Huang, C.-C.; Fang, J.-Y.; Wu, W.-B.; Chiang, H.-S.; Wei, Y.-J.; Hung, C.-F. Protective effects of (-)-epicatechin-3-gallate on UVA-induced damage in HaCaT keratinocytes. Arch. Dermatol. Res. 2005, 296, 473-481. [CrossRef]

98. Poe, B.S.; O'Neill, K.L. Caffeine modulates heat shock induced apoptosis in the human promyelocytic leukemia cell line HL-60. Cancer Lett. 1997, 121, 1-6. [CrossRef]

99. Fabiani, R.; Rosignoli, P.; De Bartolomeo, A.; Fuccelli, R.; Morozzi, G. Genotoxicity of alkene epoxides in human peripheral blood mononuclear cells and HL60 leukaemia cells evaluated with the comet assay. Mutat. Res./Genet. Toxicol. Environ. Mutagenesis 2012, 747, 1-6. [CrossRef] [PubMed]

100. Babich, H.; Krupka, M.; Nissim, H.A.; Zuckerbraun, H.L. Differential in vitro cytotoxicity of (-)-epicatechin gallate (ECG) to cancer and normal cells from the human oral cavity. Toxicol. In Vitro 2005, 19, 231-242. [CrossRef] [PubMed]

101. Fairbairn, D.W.; Walburger, D.K.; Fairbairn, J.J.; O'Neill, K.L. Key morphologic changes and DNA strand breaks in human lymphoid cells: Discriminating apoptosis from necrosis. Scanning 1996, 18, 407-416. [CrossRef] [PubMed]

102. Fairbairn, D.W.; Olive, P.L.; O'Neill, K.L. The comet assay: A comprehensive review. Mutat. Res. 1995, 339, 37-59. [CrossRef]

103. Herman, J.G.; Baylin, S.B. Gene silencing in cancer in association with promoter hypermethylation. N. Engl. J. Med. 2003, 349, 2042-2054. [CrossRef] [PubMed]

104. Esteller, M. DNA methylation and cancer therapy: New developments and expectations. Curr. Opin. Oncol. 2005, 17, 55-60. [CrossRef]

105. Roman-Gomez, J.; Jimenez-Velasco, A.; Agirre, X.; Castillejo, J.A.; Navarro, G.; San Jose-Eneriz, E.; Garate, L.; Cordeu, L.; Cervantes, F.; Prosper, F. Repetitive DNA hypomethylation in the advanced phase of chronic myeloid leukemia. Leuk. Res. 2008, 32, 487-490. [CrossRef]

106. Fang, M.; Chen, D.; Yang, C.S. Dietary polyphenols may affect DNA methylation. J. Nutr. 2007, 137, 223S-228S. [CrossRef] 